\title{
The co-operative movement and the War of Independence
}

On 21 January 1919 a meeting of twenty-seven Sinn Féin MPs at Dublin's Mansion House inaugurated Dáil Eireann. This opening of a newly constituted revolutionary Irish Parliament marked a new phase in nationalist claims for Irish self-rule. The 73 representatives from the Sinn Féin party elected at the December 1918 General Election made up the Dáil's membership, and in fulfilment of their promise to the electorate refused to take their seats at Westminster. The Irish Parliamentary Party (IPP) paid the political cost of Sinn Féin's electoral victory as the radical nationalist party reaped the benefit of growing support for a separatist political platform in the aftermath of the Easter Rising. ${ }^{1}$ The Home Rule Act that passed in 1914 after a bitter, protracted negotiation process between the IPP, Ulster Unionists and the British government proved to be a distant memory in Ireland after the war. The decision taken to suspend the Home Rule legislation at the start of the war proved fatal to the implementation of the IPP's main political goal. ${ }^{2}$ The establishment of Dáil Eireann by Sinn Féin killed the IPP's dream of Home Rule. Instead, a new generation demanded a more advanced form of political independence in the shape of an Irish Republic.

While Sinn Fein's rise appeared to mark a break in Irish political culture, the party's attempt to establish a new hegemonic agenda for Ireland drew on older traditions that included agrarian populism, revolutionary Fenianism and the urbane intellectualism of the party's founder, Arthur Griffith. Within this grand project, co-operative thought helped to shape the new variant of mainstream nationalism and formed a vital part of Sinn Féin's political economy after the war.

This Irish alternative to Westminster immediately looked to implement its own legislative platform. At the first meeting the revolutionary assembly outlined its social and economic priorities in its Democratic Programme at its first sitting, which stated that 'it shall be the duty of the Republic to adopt all measures necessary for the recreation and invigoration of our Industries, and to ensure their being developed on the most beneficial and progressive co-operative lines' ${ }^{3}$ The stimulation of the Irish economy along co-operative lines represented one 
important aspect of this aspirational programme for government. Thirty years after the establishment of the first society, co-operatives were a familiar presence in the countryside and attained the status as an important symbol of rural modernity. The ideas and arguments promoted by Plunkett and $Æ$ played a crucial role in nurturing sympathy for co-operative ideas among Sinn Féin's intellectual wing. What began as a contentious and controversial intervention into the Irish economy became a normalised institution that shaped everyday rural life. Their presence still provoked rancour in some quarters, but by the end of the war, the co-operative movement provided a source of economic ideas for those who demanded a radical change in how their country was governed.

The Dáil's attempts to promote limited governmental programmes represented a real, subversive attempt to create a counter-state. ${ }^{4}$ The assembly represented a potent symbol of popular resistance against British power in Ireland and acted as 'a source of legitimacy for fighting men in the guerrilla war that followed'. Although the new legislative assembly proposed to represent the whole island of Ireland, Ulster Unionists unsurprisingly declined the invitation to sit in Dublin. To counteract the Dáil's influence, Westminster passed the 1920 Government of Ireland Act, which provided for two parliaments in Ireland - one each in Belfast and Dublin. This established the partition of Ireland in principle as the six north-eastern counties became Northern Ireland. Technically the other twenty-six counties constituted an entity called Southern Ireland, but this iteration of an Irish polity emerged stillborn as the contestation of Ireland's political future intensified. ${ }^{6}$

The co-operative movement experienced at first hand the violence which characterised the revolutionary years between the end of the Great War and the establishment of the Irish Free State in 1922. To what extent a revolution occurred in Ireland remains an open question in the historiography. For example, Michael Laffan argues that the Irish revolution took 'nationalist, political and military forms' but made no attempt to instigate radical social change. ${ }^{7}$ However, this notion of what constituted the nationalist form requires greater definition. Important works examining social change at a local level highlight how social and economic questions affected Irish life in this period with the issues of land ownership and agrarian violence suggesting that questions of property and status helped to fuel the political upheaval. ${ }^{8}$ Fergus Campbell convincingly argued that the revolutionary impulses found in Sinn Féin provided continuity with the land agitations of the late nineteenth and early twentieth centuries. ${ }^{9}$ Sinn Féin drew support from these rural grievances that constituted dissatisfaction with the status quo. The apparent embrace of co-operative ideals by Sinn Féin provided an opportunity for the IAOS's co-operative principles to become part of the discussion about what a future Irish state might look like.

The IAOS came through the war with rediscovered confidence and cause for optimism. Co-operative societies continued to organise working practices in 
the countryside, and farmers derived financial benefit from their membership. The movement stood on the threshold of new opportunities as membership numbers reached a high watermark at this time. The establishment of a new general-purpose society that carried out a more diverse trade provided a cause for some cheer among the movement's leaders. The fact that Dáil Eireann's Democratic Programme made a commitment to Irish industrial development also offered an opportunity to advance the IAOS's influence over a potential government in waiting. Concerted efforts to bring about measurements that promoted economic development despite the Dáil's limited resources did take place. In relation to agricultural development, the co-operative movement offered a ready-made instrument through which the rural policies might be carried out. From the vantage point of the IAOS, the shift in the political landscape raised the possibility of advancing attempts to construct a Co-operative Commonwealth. However, any prospects of a peaceful transition into the next phase of a more cooperative economy soon dissipated. The Irish War of Independence saw the country collapse into a violent guerrilla conflict fought between the Irish Republican Army (IRA) and British security forces, which lasted from 1919 to 1921. Co-operative creameries suffered greatly in the conflict as they found themselves targeted by Crown forces in reprisals aimed at local communities in the wake of IRA activities.

This chapter is divided into three sections. The first examines how the cooperative movement exerted a significant intellectual influence within the Sinn Féin movement. Despite the co-operative movement's official non-political status, radical nationalists appropriated their language of rural construction as another aspect of an Irish nation-building project. The readily accessible reservoir of co-operative ideas aligned to one of Ireland's largest mass-membership organisations offered a generation of would-be legislators a source of policy ideas for the future. This potential utility guaranteed the IAOS a role to play within whatever iteration of an Irish nation-state came out of the conflict. The second section examines the co-operative movement's own developmental trajectory as it started to experiment with new types of co-operative businesses in the immediate aftermath of the Great War. The timing of such experimentation proved fatal as violence stunted the movement's ability to diversify $-\mathrm{a}$ factor that helped to contain co-operative energies firmly within the dairying sector. The chapter ends with an exploration of the movement's experience of violence during the War of Independence. The resilience of the movement built up over previous decades left the co-operative movement well positioned to endure state-sponsored attacks. Such experiences ensured that co-operative societies became increasingly nationalised as tools for economic development because of victimisation by Crown forces. It also allowed the IAOS to position itself as a national institution for social and economic development on the eve of independence. 


\section{Co-operation, nationalism and labour}

\section{Co-operation and Sinn Féin}

Ireland caught the interest of a new wave of foreign investigators and journalists keen to understand the dynamics of political change after the Great War and the co-operative movement stood out among the motley forces at work. In part, the reason for this attention stemmed from $Æ$, whose reputation as a literary man of letters and an economic thinker lent him an international stature. Æ's was a familiar name outside Ireland, and his house provided a first port of call for intrepid investigators who wanted to grasp the dynamics of a changing Irish Question. One of this number, Ruth Russell, worked as a journalist with the Chicago Tribune and published an account of her visit entitled What's the Matter with Ireland? As Russell travelled across an Ireland descending into violence and unrest, she concluded that the Irish Question turned on the social and economic problems she encountered on her travels. The cause of unrest resided in the fact that Ireland was poor: 'poor to ignorance, poor to starvation, poor to insanity and death. And that the cause of her poverty is her exploitation by the world capitalist next door to her.'

Russell's grand tour brought her into contact with political and social activists who provided answers to her questions about the unsettled state of the country. In urban areas she met with labourers who argued that a Workers' Republic provided the only means to end poverty. Her forays into the countryside revealed that in the 'villages and country places where the co-operative movement is growing strong, there are those who believe that the new republic must be a co-operative commonwealth'. ${ }^{10}$

Ruth Russell visited Æ's home during one of his regular Sunday soirées where intellectuals gathered to discuss a number of topics that ranged across politics, the arts and economics. Russell observed first-hand the high regard in which the visitors held $Æ$ who she described as 'the north star of Ireland' and someone "who gives ear to all sincere radicals, Sinn Féiners and "Reds". The opportunity to talk with $Æ$ in his home 'goes far ... towards easing the strain on the taut nerves of the Sinn Féin intellectuals who attend them'. Importantly, the geniality of $Æ$ provided him with frequent opportunities to impress his views on the peaceful revolution of co-operation' on those at the heart of the Sinn Féin project. ${ }^{11}$

Russell devoted a chapter of her book to the co-operative movement and encountered a movement that promoted rural development and encouraged a spirit of self-reliance among its members. Speaking to Russell just before violence broke out, Æ optimistically assessed the contemporary situation as one where 'Ireland can and is developing her own industries through co-operation'. However, $Æ$ viewed British government in Ireland as an impediment to this development and undermined farmers' efforts to improve the agricultural sector through their 
own efforts. He supported 'the building of a co-operative commonwealth on co-operative societies', but felt English rule prevented this outcome because its imperial lens proved too large to see the importance of government at the village level.

She [Ireland] is developing [industries] without aid from England and in the face of opposition in Ireland. England, you see, is used to dealing with problems of empire - with nations and great metropolises. When we bring her plans that mean life or death to just villages, the matter is too small to discuss. She is bored. ${ }^{12}$

Ireland needed a governmental template that prioritised the rural village, which Æ believed was the backbone of the nation. The recent years of wartime economic management emphasised the veracity of this view for $Æ$, which he passed on to interested observers such as Russell.

At this time, $Æ$ directed Russell, to visit one of the new types of society in Dungloe, County Donegal. Æ directed Russell there to understand

the poverty of the Irish countryside, of the extent that the poverty is due to the gombeen men ... and of the ability of the co-operative society to develop and create industry even in such a locality. ${ }^{13}$

There Russell met with the local co-operative activist named Patrick Gallagher. ${ }^{14}$ Gallagher had moved from Donegal to Scotland in 1899 where he saw the economic benefits provided to people there by the presence of co-operative stores. Gallagher returned to Donegal in 1902 determined to establish a similar cooperative society which opened as Templecrone Co-operative Society in 1906. Templecrone stood out against the backdrop of the IAOS's societies and it shared similarities with the retail societies promoted by the Co-operative Wholesale Society (CWS). It started as a small store to make collective purchases of manure for local farmers, but gradually expanded to serve the requirements of the local population. Gallagher recounted the impact of Templecrone Co-operative Society as one that freed the local population from indebtedness to local traders and shopkeepers by loosening their financial hold upon locals: 'Thank God the slave mind is gone. If it is in any other part of Ireland today, it is not in the Rosses. ${ }^{\text {'15 }}$

Ruth Russell encountered a thriving society involved in many aspects of local life, which encouraged 'the hints of growing industry'. This reflected the local influence of the United Irishwomen. These included a bacon-curing plant, the co-operative production and sale of eggs, the rental of modern farm machinery to members, a bakery, orchard, beehives and a woollen mill, which employed local women who no longer planned to emigrate to America or Scotland 'as their older sisters had had to plan'. The society's managers intended to develop other local industries such as fishing and local transportation. Besides offering affordable provisions, the society provided locals with a space for social interaction. The co-operative hall held dances, lectures and other entertainments. Furthermore, 
the society pioneered a concern for the social welfare of members, employing a nurse 'to care for the mothers at child-birth ... the first nurse who ever came to work in Donegal'. ${ }^{16}$ Russell concluded that Templecrone Co-operative Society successfully prevented the economic exploitation of local inhabitants by reducing the influence of local traders and shopkeepers.

Irish co-operation demanded the attention of foreign visitors. The movement's work enthused Ibrahim Rashad, an Egyptian nationalist who published his travelogue An Egyptian in Ireland in 1920. Having studied economics and lived in England, Rashad wanted Egypt to attain 'her political emancipation, her economic freedom [and] her social uplifting'. Rashad travelled to Ireland as part of the responsibility of every 'intellectual among the rising generation in every country, especially in those countries which circumstances have placed in a backward position, to investigate and to make known those movements in other lands from which their own people may learn'. Like Ruth Russell before him, Rashad visited Æ, who the young Egyptian cited as a chief intellectual influence: 'His views of ideals and realities ... fill the young and ardent with the desire to do great things. His inspiring influence on the rising generation cannot be exaggerated.' Æ gave Rashad an informal education on Ireland and co-operation. As a result, Rashad grew enthused by the possibilities for national revival offered by co-operative principles as practised by the Irish:

Here the spirit of association and power of organisation seemed to have full play in many of the ways of life. As applied to political and social questions they appeared to be as effective as when applied to economics. I now discovered that my enthusiasm for the Co-operative Movement was to lead me further than the desire merely to improve the economic position of my people. It was to show me what the power of organisation and force of associated effort can do in every department. ${ }^{17}$

Rashad observed what he viewed as one of the Irish co-operative movement's most powerful attributes, which was that once the principle of economic autonomy was practised widely then the desire for political autonomy naturally grew. Rashad recognised something denied by Horace Plunkett at the IAOS's inception - namely that the establishment of a co-operative society represented an inherently political act. Rashad left Ireland convinced that co-operation offered a means to attain social, economic and political independence as he wed principles of mutualism and co-operative economic organisation to the assertion of a nationalist identity.

Within Irish nationalist circles, the connections with the co-operative movement grew more pronounced. Æ's influence over Sinn Féin intellectuals grew throughout the early twentieth century. His prolific output through books and journalism meant he provided constant commentary upon unfolding political events from a co-operative perspective. In particular, his 1916 treatise, The National Being, provided an important intellectual touchstone for Sinn Féin intellectuals such as Darrell Figgis, Aodh de Blacam and Patrick Little. The first two individuals 
published a series of books and articles that argued in favour of Sinn Féin policies, while Little edited the Sinn Féin newspaper, New Ireland. All displayed this book's influence within their own writing. ${ }^{18}$ The language of co-operation employed by these writers granted a social and economic coherence to the vision of a future independent Irish nation-state they aimed to create.

Darrell Figgis's contribution to the intellectual development of the Sinn Féin project bore the imprimatur of co-operative idealism. Figgis, a regular visitor to Æ's house, spent several stints in prison on account of his political activities. He published nationalist propaganda and enjoyed close access to Sinn Féin leaders, becoming a trusted confidant to Arthur Griffith, the Vice-President of Dáil Eireann. After independence, he played a key role in writing the Irish Free State's first constitution. ${ }^{19}$ Figgis argued in 1916 that $Æ$ 's economic and social philosophy provided an ideal foundation for an Irish nation-state as it offered 'a distinct nationality with its own conception of civilization; and [Æ] would house that nationality in a distinct State worthy of the praise of noble men' ${ }^{20} \mathrm{~A}$ year later Figgis identified the co-operative society as the means through which Irish farmers had already started to build this modern state. Although Figgis believed that Ireland existed already as a nation, it had yet to graduate to the rank of 'a Sovereign State'. Figgis argued that farmers seized upon the co-operative ideology as a means to recapture a sense of an old statehood that existed in an idealised Gaelic past. These farmers 'turned their co-operative societies into rural communities that were a re-birth in modern conditions of their old stateships'. ${ }^{21}$ According to Figgis, the conditions for a return to a Gaelic state arrangement already existed in those rural communities engaged in co-operative activity. Rural co-operatives provided a glimpse into the independent Irish nation-state yet to come.

Aodh de Blacam, another Sinn Féin publicist, also drew heavily from $Æ$ 's well and later described the artist as someone who 'developed a plan for a co-operative commonwealth that amounted to a draft constitution'.22 In de Blacam's own work written during the years before Irish independence, he argued that Sinn Féin reflected the mood of the nation, which he primarily defined as rural. ${ }^{23}$ This reification of the rural represents an important motif of the separatist nationalist élite, who were largely from an urban, middle-class professional background. ${ }^{24}$ Between 1918 and 1921 de Blacam published several books in which he argued for a national policy to promote and protect the agricultural mode of life. ${ }^{25}$ De Blacam's view that 'the future of Ireland lies in Co-operation no observer of the times can doubt', revealed a conviction such principles could resolve the Irish Question. He understood that the co-operative movement's influence over rural life resulted from its long-term, gradual extension throughout the country. However, its continued success relied upon an ability to attract support from a new generation: 'Co-operation ... had to be preached, as in the wilderness, for the space of a generation, but today every young man of intelligence 
... accepts co-operation as the progressive policy. ${ }^{26}$ De Blacam echoed the arguments made by Figgis when he asserted that 'every Irish social thinker envisages the Gaelic polity as a rural polity'. This definition of Gaelic was important as it equated rurality with a more authentic type of Irish society that had been lost. De Blacam argued that Irish people regarded the 'great industrial cities of Britain or America ... as horrible perversions of the natural order'. He conceded that the 'Irish objection of urban concentration is factitious', but continued, 'when all allowances are made it is deep-rooted in the Irish mind'. ${ }^{27}$

The adoption of co-operative values set Sinn Féin apart from the constitutional nationalists. Whereas the IPP treated the co-operative movement with outward hostility, Sinn Féin embraced its ideas. Just as the IPP represented an older generation and the past, Sinn Féin exuded a youthful, modern appeal as they positioned themselves as the political movement of an Irish future. It was the young farmer who walked 'the progressive path'. The archetypal Sinn Féin supporter read 'modern Irish literature, and finds every one of the intellectual leaders of the country preaching co-operation [and] sees no one defending the cause of the old regime of traders who grew rich on selling bad seeds and inferior manures' ${ }^{28}$ The years of Homestead editorials and IAOS rhetoric, in which the co-operator stood in opposition to an economic system rigged by traders and gombeen men, found its way into nationalist critiques of social conditions. Links between the spread of co-operation and wider cultural development echoed the objectives that animated the cultural revivalists in the 1890 s. $^{29}$ De Blacam highlighted the co-operative movement's attempts to enrich cultural life as further evidence of their role as a force for national regeneration. For example, Enniscorthy Cooperative Society displayed its modern credentials when it established a cinema for the local community. In this way, co-operation provided a mechanism which contained 'the possibility of Irishising the people's amusements', and in the near future societies could become 'the most effective patrons of Irish music, Irish drama and Irish talent that [the public] have ever enjoyed'. ${ }^{30}$

Any commitment to co-operative principles among leading Sinn Féin individuals is likely to have varied in its levels of enthusiasm. Nevertheless, an appropriation of the language of co-operation emerged as a trope that peppered Sinn Féin commentary on social and economic matters. At times, this commitment went beyond the pages of political treatises. In June 1919, Sinn Féin ordered all local party branches to 'promote the organisation of Co-operative Societies to deal with neglected resources and industries' ${ }^{31}$ Michael Collins, one of the Republican leaders and the Dáil's Finance Minister, advocated that industrial development in Ireland needed to occur on 'on co-operative lines rather than on the old commercial capitalistic lines'. ${ }^{32}$ The Dáil showed some support for co-operative principles and institutions in pursuit of their counter-state through some of the reforms they proposed to pass as legislation. As such these attempts to pass remedial legislation suggested a degree of practical commitment to co-operative 
principles beyond the pages of intellectual treatises, which arguably helped to manifest Arthur Griffith's aim that Sinn Féin display a 'spirit of self-reliance. ${ }^{33}$

Æ cautiously welcomed these nationalist overtures in April 1919. On one level, he applauded this interest in co-operative ideals, which seemed 'to have many voluntary propagandists, for we find Irish papers on all sides reporting speeches in which the future Ireland is spoken of as a Co-operative Commonwealth'. However, he questioned the sincerity of these 'new propagandists of the Co-operative State whose advent in the field of co-operative effort we welcome'. Æ challenged the new advocates to 'define more clearly the kind of social order they are working for, and the steps by which they propose to attain what they desire. ${ }^{34}$

The next month, the Dáil provided $Æ$ with some policy evidence. Ernest Blythe, the Dáil's Director of Trade and Commerce, argued for the organisation of the Irish economy along co-operative lines, stating that this provided 'the only feasible method of combating foreign trusts and combines. ${ }^{35}$ Blythe had worked at the Department of Agriculture and Technical Instruction (DATI) during Horace Plunkett's time as Vice-President when co-operative principles informed official agricultural policy. ${ }^{36}$ Under Blythe's direction, a pragmatic working relationship between the IAOS and Dáil Eireann emerged. On 6 May 1919, Sinn Féin's executive urged all party branches to support the establishment of co-operative societies and the Dáil formed a commission to study 'the whole question of co-operation in Ireland'. The commission's committee included prominent IAOS figures such as Æ, Fr O'Flanagan, Edward Lysaght (the latter two members of the National Committee) alongside the Dáil's Director for Agriculture, Robert Barton. By August, Arthur Griffith had produced a pamphlet urging that cooperative organisation be applied to matters of trade and distribution and President of the Dáil, Eamon de Valera, communicated from America that he 'endorsed the idea of the Co-operative Commonwealth. ${ }^{37}$ Later that year the Dáil grew more involved in the IAOS's day-to-day operations as Robert Barton was co-opted onto its governing committee. ${ }^{38}$ Two years later, Ernest Blythe joined Barton on that committee, which provided Sinn Féin with an insight into the administration and structure of the movement. ${ }^{39}$ This formalised a working relationship between an insurgent government and the premier agency of rural expertise, which provided the basis for a long-term relationship.

Arthur Mitchell argued that Sinn Féin's commitment to co-operatives declined within months. Instead, the party concentrated its attention and resources upon local elections in 1920 as it looked to build on its successes as an efficient electoral machine. ${ }^{40}$ Electoral successes remained the immediate priority for Sinn Féin, but between 1919 and 1921 members of the Dáil still aimed to demonstrate that they represented a serious government and social issues received due care and attention. For example, the question around land ownership remained contentious. The 1903 Wyndham Land Act legislated for the break-up of estates 
and the transfer of land to the tenant farmers. ${ }^{41}$ Perceived as a legislative solution to previous decades of agrarian unrest the persistence of land ownership and distribution as a controversial issue continued to reverberate. ${ }^{42}$

In December 1919, a Dáil committee investigated the possibility of creating a central co-operative bank. This resulted in the foundation of the National Land Bank as a way to provide credit to farmers in order to continue the extension of land ownership among farmers. The National Land Bank, or Banc na Talmhan, was registered under the provisions of the 'Industrial and Provident Societies Acts as a co-operative institution' and aimed to ensure the circulation of Irish money remained within Ireland and 'establish a financial centre for their interests' ${ }^{43}$ At a later date, Ernest Blythe would describe the rationale behind its foundation as a means to prevent 'the national struggle from being turned into a land war'. ${ }^{44}$ However, the co-operative structure applied to this banking institution demonstrated a serious level of commitment to the pursuit of co-operative principles beyond idle talk.

The Dáil appointed Lionel Smith-Gordon as the bank's managing director. Born in England and educated at Eton and Oxford, ${ }^{45}$ Smith-Gordon worked at the University of Toronto until 1912. He later recalled that around that time he 'became very much interested in the co-operative movement in Ireland. I went there and soon became a revolutionist. ${ }^{46}$ Smith-Gordon moved to Ireland in 1914 where he worked at the Co-operative Reference Library in Plunkett House and championed the role of co-operatives in Irish and European economic development. Smith-Gordon fitted the criteria required as bank manager by virtue of being 'a gentleman who has considerable experience in connexion with agricultural banking operations' ${ }^{47}$ His intellectual development mirrored that followed by other Irish nationalists as he becane attracted to the philosophy of Sinn Féin through his work for the co-operative movement.

Lionel Smith-Gordon's appointment at the National Land Bank brought him into close orbit with Sinn Féin officials and his advocacy of co-operative principles became shot through with political separatism. Critics of Sinn Féin singled out Smith-Gordon for attack. In September 1921, playwright and Ulster unionist, St John Ervine, launched a scathing attack upon Sinn Féin in The Times. Ervine's criticisms rested on his ability to demonstrate his impeccable Ulster credentials by tracing his ancestry back for at least 300 years. That record granted Ervine 'some claim to the title of Irish'. In contrast, Ervine accused key members of Sinn Féin as unable to make a claim to genuine Irishness. Ervine identified Eamon de Valera, the Dáil's President, as 'a citizen of the United States, born in New York of a Spanish father and an Irish mother'; Arthur Griffith was 'a Welshman, who, like Medea, is "sullen-eyed and full of hate"; and Erskine Childers, 'the most extreme adviser of Sinn Féin', was in the end, 'a very gallant Englishman'. Ervine then asserted that 'one of the ablest officials the Sinn Féiners possess in 
their non-political activities is an Englishman, Mr Smith-Gordon'. ${ }^{48}$ Smith-Gordon viewed himself as a patriotic Irishman at this stage and took umbrage with Ervine's portrait, which provoked a strong defence against the accusation of 'Englishness'. 'Honoured by being mentioned among the dramatis personae of Mr Ervine's Wonderland', Smith-Gordon rubbished the claim that he was 'an official possessed by Sinn Féin'. Instead, he defined his occupation as a means to 'serve my country as a manager of a registered company'. He stressed: 'I am not an Englishman, by blood, temperament, domicile, citizenship, or outlook', and claimed that, 'I try to atone for an alien upbringing by living in and for my country. ${ }^{49}$

As manager, Lionel Smith-Gordon helped to embed the co-operative society as a developmental instrument among Irish policymakers and laid out the scope of this ambition in 1921 when he claimed 'we have to arrive at quite a new point of view - the attitude that a bank is a national institution with a national objective. ${ }^{50}$ The bank's charter asserted that, 'The National Land Bank is an Irish institution founded to assist in the rebuilding of Ireland's prosperity, the restoration of her population and the securing of her economic independence'. 51 The bank's work was of 'an experimental nature'. Its primary objective was to provide mortgages to co-operative societies made up of landless farmers who could then purchase property. ${ }^{52}$ The way in which banking policy might achieve a national objective was through a mass land purchase scheme. From the outset, Smith-Gordon looked beyond this initial objective of land purchase and looked to position the National Land Bank as a means through which a more co-operative economy might be realised - one in which a national bank provided the finances to extend the co-operative movement from a producer movement to one in which a cooperative retail sector might flourish. ${ }^{53} \mathrm{He}$ argued:

The ideal is to create co-operative communities of men who will work in harmony with one another and help one another to get the highest possible yield out of the land, to standardise the produce, to brighten the life of the countryside, and to do away with the existing class distinctions and feelings of bitterness which arise from unequal distribution of wealth and opportunity. ${ }^{54}$

The National Land Bank was founded with a nominal share capital of $£ 406,000$. ${ }^{55}$ It received an initial $£ 203,000$ investment from the Dáil and by June 1921, the bank had loaned out $£ 315,000$. Most of this money funded land purchases, but several loans funded other industries such as fisheries. Importantly, all capital flowed through co-operative societies utilised as instruments of nationalist development. ${ }^{56}$ The bank only achieved limited success. During the War of Independence, Crown forces frequently raided branches and hostility from established banks frustrated any attempt to diversify into commercial banking. After independence, the establishment of an Irish Land Commission superseded the functions of the bank as land distribution policies became centralised. ${ }^{57}$ 
However, the National Land Bank offered a brief but potent symbol of a national economic policy based on co-operative principles. It also showed that Sinn Féin representatives proved willing to work with co-operators in order to achieve its policy objectives.

\section{Co-operation and Labour}

Co-operative principles also found a receptive audience within the Irish labour movement. With its collectivist political economy, trade unionists and labour activists advocated co-operative ideas with somewhat different emphases to the principle espoused by the IAOS. James Connolly served as the intellectual figurehead of the labour movement in the early twentieth century. Connolly's execution, as one of the leaders of the 1916 Easter Rising, deprived the labour movement of its most dynamic leader. Prior to that, he had engaged with co-operative ideas in his writings on Irish labour history. He concluded the Co-operative Commonwealth represented an appropriate form of social organisation for Ireland. However, Connolly's conception of a Co-operative Commonwealth differed from that advanced by the IAOS. From organised labour's perspective a focus on the consumer instead of the producer better served working-class aspirations. If a more satisfactory form of co-operation were to take root in Ireland, rural and urban co-operators needed 'to find a common basis in order that one might support and reinforce the other'. ${ }^{58}$ Connolly identified the failure to achieve this objective as an inherent flaw in the IAOS's vision. Instead, in line with some of the syndicalist views that circulated around the Irish labour movement before the war, Connolly advocated an industrial strategy that placed the interests of all workers under the leadership of one single trade union. This offered the most effective way of achieving a 'Social Administration of the Co-operative Commonwealth in the future. ${ }^{59}$ Fr Finlay of the IAOS vociferously disagreed with Connolly's conception of co-operative organisation, which he viewed as a worrying tendency towards a more materialistic form of political activism and a threat to the IAOS's pre-eminence in the field of organising. ${ }^{60}$

During the Dublin Lockout - a major industrial dispute that occurred between August 1913 and January 1914, involving about 20,000 workers - the Manchesterbased CWS provided an important source of material and moral support for strikers and their families. The first shipload of food supplies sent by the CWS, with the support of the Trades Union Congress, to support families in dire need of assistance arrived in Dublin on 27 September 1913. The SS Hare delivered much needed food to over 18,000 people who been supplied with food tickets by local trade union societies, and the CWS's correspondent reported that as "every package bore the letters "CWS" ... the whole of Dublin is discussing the growing power of this people's organisation'. ${ }^{61}$ Supply-laden ships continued to cross the Irish Sea to Dublin until the end of the strike in which almost 1.8 million loaves of bread were distributed along with other staples such as margarine, 
clothing, tea and sugar. ${ }^{62}$ The consumer-oriented version of the Co-operative Commonwealth, represented by the urban CWS movement, resonated within the trade union movement more than the rural producers' movement. Trade unionists continued to promote this consumerist model in the years after Connolly's death. $^{63}$

Potential for a fruitful relationship between labour and rural co-operators existed by the end of the war. In the wake of the Russian Revolution, the confidence of international labour movements increased. In Ireland, the Russian Revolution galvanised the labour and co-operative movements and contributed to demands for social change. In February 1918 the leader of the Irish Labour Party, Tom Johnson, reflected upon the implications of the Russian Revolution in an article entitled, 'If the Bolsheviks Came to Ireland'. Johnson found an Irish equivalent to the Russian soviets in

the trades councils, the agricultural co-operative societies, and ... the local groups of the Irish Republican Army. An Irish counterpart of the Russian revolution would mean that these three sections, co-operating, would take control of the industrial, agricultural and social activities of the nation. ${ }^{64}$ (Emphasis added)

Such rhetoric provided no reassurance to a British government alive to the threat that militant Irish workers posed to its authority, but also raised the spectre of revolutionary potentialities attached to co-operative societies.

Æ echoed Johnson and welcomed revolutionary developments in Russia. Writing in the Irish Homestead, he argued that the Russian Revolution represented a vindication of co-operative principles. In the revolution's immediate aftermath in November 1917, Æ wished that

revolutionaries in Ireland were afflicted with something of the Russian madness and realised, as the Russians do, that economic institutions are at least as of much importance as political institutions ... A co-operative society is an economic republic. ${ }^{65}$

In March 1919, such a positive appraisal of the Russian social order remained part of Æ's worldview. In an article entitled, 'All Co-operators Now!' he presented Russia as a potential model for a future Irish state:

We are not advocating compulsory co-operation in Ireland, but we find it impossible to be indignant with a State which carries the co-operative idea so far as the Russian Republic has done... there is only one country in the world where all distribution is on co-operative lines, and, personally, we hope that system will never be upset, whoever may come or go as leaders of the Russian people. ${ }^{66}$

Æ's enthusiasm for the revolution did not survive 1920 when the Bolsheviks nationalised the co-operative movement there. ${ }^{67}$ However, in 1919 his admiration led him to consider how co-operative organisation and labour's interests might be more comprehensively addressed under the IAOS.

In January 1919, the leaders of the Irish Labour Party contributed to the Dáil's Democratic Programme. The party stepped aside to provide Sinn Féin 
with a clear run, but still looked to influence policies within the Dáil. In an earlier draft of the document, Tom Johnson indicated the labour movement's interest in co-operative societies in a sentence:

It shall be the purpose of the government to encourage the organisation of people into trade unions and co-operative societies with a view to the control and administration of industries by the workers engaged in the industries. ${ }^{68}$

Ultimately, the labour movement and IAOS diverged on how best to achieve this end. The largest and most militant trade union in Ireland was the Irish Transport and General Workers' Union (ITGWU). Founded by Liverpool-born trade union activist, James Larkin, in 1908, the union possessed 14,500 members in 1916. By 1919, these figures grew to $101,917 .^{69}$ The labour movement's radicalism manifested during 1917-23 through a variety of tactics, such as strikes and workplace takeovers. Terms such as 'Workers' Republic', 'industrial unionism' and 'co-operative commonwealth' peppered the labour movement's rhetoric. The ITGWU advocated a revolutionary syndicalist ideology that encouraged the creation of a working-class political movement under its leadership.

During 1918-20 the ITGWU expanded into the countryside as it recruited heavily among agricultural labourers. ${ }^{70}$ As such, a rural labour militancy emerged from the ITGWU's 'efforts to develop a working-class counter-culture, through co-operatives, May Day parades, aeríochtaí [festivals], and labour newspapers'. ${ }^{71}$ In County Kerry, labour organisations turned to co-operative principles to secure the economic interests of their members. In November 1918, the Irish Homestead reported the establishment of a workers' co-operative store in Tralee. The enthusiasm shown by workers for the new venture in a town where 'local opposition usually barred the way' appeared to highlight a great change that occurred under the cover of the war - the 'capitalist fear of organised labour'. ${ }^{72}$ The following January, the ITGWU established another co-operative store in the market town of Listowel 'for the benefit of the workers' ${ }^{73}$ Located in County Kerry's most urbanised areas, these co-operative stores reflected the ITGWU's desire to use co-operative methods to benefit local working-class consumers and highlighted an appetite for a new type of retail in the area.

This incursion into the IAOS's heartlands led to an uneasy relationship with organised labour. By May 1919, antagonisms between rural co-operators and the trade union movement emerged. Æ hoped that workers would continue to establish co-operative societies, but suggested that trade unions and the IAOS should co-ordinate their efforts. He wondered if:

trade union leaders would communicate with the [IAOS], so that investigation may be made, and it may be seen whether labour would be better advantaged by coming in with farmers in starting a single strong society catering for both. ${ }^{74}$

This incorporation never occurred as rural labourers looked to the ITGWU for leadership. However, the challenge offered by the labour movement concentrated 
the minds of the IAOS's leaders about how the movement might break into the area of rural consumption.

\section{New explorations in co-operation}

The IAOS's position by the end of the war appeared mixed, but cause for optimism existed among co-operators as 1919 dawned. Wartime saw an increase in agricultural income and farmers rallied around the IAOS with a generosity not previously seen. Dues and subscription for 1920 amounted to almost $£ 9,000$, or roughly two-thirds of IAOS's total income for that year. ${ }^{75}$ In 1920, membership for the movement reached a peak of $157,766 .^{76}$ These figures reflected a greater affluence among farmers, but also suggested that a greater number of rural inhabitants recognised that co-operative societies offered one way to acquire cheap agricultural implements at a time of rising living costs. The war led to an overall increase in the co-operative movement's trade turnover by 21.7 per cent in 1919 compared to 1914 . Dairying remained the IAOS's most important sector, but throughout the war creameries increased turnover by only 3 per cent (see table 5.1). Although an unspectacular level of growth, this figure showed the resilience of co-operative creameries to hold their position at a time of declining milk supplies. Farmers in the dairying heartlands of Munster, where more than half of Irish milk production occurred, remained reliant upon the creamery as a source of income. ${ }^{77}$

Outside dairying, the co-operative credit movement collapsed during the war as activity contracted by 256 per cent. This collapse proved indicative of the IAOS's neglect of co-operative credit after 1914, itself partly a result of wartime affluence. In other areas, flax societies increased trade by 721 per cent, but this

Table 5.1 Financial position of IAOS in 1919

\begin{tabular}{lrrrr}
\hline Type of society & \multicolumn{1}{c}{$\begin{array}{l}\text { Turnover for } \\
\mathbf{1 9 1 9}(\mathfrak{E})\end{array}$} & $\begin{array}{c}\mathbf{1 9 1 9} \text { turnover in } \\
\mathbf{1 9 1 4} \text { prices }(\mathfrak{E})\end{array}$ & $\begin{array}{l}\text { turnover for } \\
\mathbf{1 9 1 4}(\mathfrak{E})\end{array}$ & Increase \% \\
\hline Dairy society & $7,047,079$ & $2,818,856$ & $2,731,628$ & 3 \\
Agricultural & $1,279,471$ & 511,788 & 197,146 & 160 \\
$\quad$ societies & & & & \\
Poultry societies & 246,599 & 98,639 & 65,487 & 51 \\
Credit societies & 33,834 & 13,533 & 52,926 & -256 \\
Misc. societies & 696,649 & 278,659 & 187,826 & 48 \\
Flax societies & 47,791 & 19,116 & 2,328 & 721 \\
Federations & $1,807,160$ & 722,864 & 429,383 & 68 \\
Total turnover & $\mathbf{1 1 , 1 5 8 , 5 8 3}$ & $\mathbf{4 , 4 6 3 , 4 3 3}$ & $\mathbf{3 , 6 6 6 , 7 2 4}$ & $\mathbf{2 1 . 7}$ \\
$\quad$ for movement & & & & \\
\hline
\end{tabular}

Source: IAOS, Annual Report, 1920. 
accounted for less than 0.5 per cent of the IAOS's total business. Poultry societies expanded trade by 50 per cent, while trading federations increased turnover by 68 per cent. Both sectors remained a minor part of the co-operative movement's total business. The IAOS's overall financial position improved during the war but the movement remained reliant upon an annual subsidy from the Development Commissioners. ${ }^{78}$ A pressing immediate concern stemmed from the fall in wartime dairy production. The compulsory shift towards greater tillage farming during the war occurred in an abrupt manner with a detrimental effect on the level of Irish dairy output. Lionel Smith-Gordon claimed that the situation deteriorated further due to 'the slaughter and export of milch cows, which, in spite of official denials, have been brought about by war conditions and by blunders incidental thereto' ${ }^{79}$

A new, and potentially fruitful, set of relations between the IAOS and DATI beckoned in 1919. T.W. Russell retired from the DATI in late 1918 and Hugh Barrie, an Ulster Unionist MP, replaced him as Vice-President until November $1921{ }^{80}$ However, from the outset, Barrie's time in office was beset by poor health and he made less impact in office than either of his predecessors. T.P. Gill, Secretary of the DATI, carried out many of Barrie's public duties. ${ }^{81}$ A more benign relationship beckoned between the two agencies of rural development as IAOS officials once again began to acquire positions upon investigative committees established by the DATI. In late 1919, Robert Anderson and Harold Barbour represented the IAOS on the committee appointed to examine the causes behind the declining Irish milk supply. ${ }^{82}$ As the largest operator of creameries, the cooperative movement provided an important service to the state in Ireland, as it proved able to efficiently collect and analyse data that related to the dairy industry. The committee drew heavily on evidence provided by creameries, which offered a window onto the intricacies of the economy in the dairy plains of Ireland. A sample taken from six creameries in Counties Limerick and Kerry showed how milk yields declined drastically by 16 per cent during a period that covered the implementation of wartime controls (table 5.2).

A weakened dairy industry offered serious cause for concern to the IAOS as its reputation and strength derived from its creamery sector. As the economy adjusted to post-war conditions, the rivalry between private and co-operative creameries re-emerged. The rates paid to milk suppliers varied across districts and depended upon the concentration of creameries. The fierceness of the rivalry

Table 5.2 Declining milk supply to six creameries in counties Limerick and Kerry

\begin{tabular}{lccc}
\hline Year & $\mathbf{1 9 1 6}$ & $\mathbf{1 9 1 7}$ & $\mathbf{1 9 1 8}$ \\
\hline Milk supply (gallons) & $4,067,000$ & $3,840,000$ & $3,420,000$ \\
\hline
\end{tabular}

Source: HCPP (Cmd. 808). 
between co-operative and proprietary creameries played out most persistently in the south-western region of the country where conditions proved most suitable for dairy farming. ${ }^{83}$ Co-operative society committees accused privately operated rivals of unscrupulous price-fixing. In August 1919, co-operative societies in Kerry held a conference which broached the subject of co-ordinating their work in an effort at

combating the methods of Proprietary Creameries in paying artificial prices for milk in districts where Cooperative Societies exist while paying much lower prices per gallon in districts where they are no Cooperative Societies. ${ }^{84}$

In 1919, a legal challenge to the way in which co-operative creameries organised their milk supply threatened to unravel the IAOS network. Private creameries looked to weaken the co-operative movement's hold over the dairy industry through a legal challenge against the binding rule. In 1908, the IAOS introduced a controversial binding rule, which tied members into a permanent relationship with their co-operative society, and forbade them from supplying milk to any other creamery. If a member refused to supply good milk to their society, the committee penalised that member at the rate of one shilling per cow for each day milk was withheld. ${ }^{85}$ This echoed the Danish system which bound farmers to the co-operative society for a period of up to seven to ten years and operated with successful results. ${ }^{86}$ Unlike Denmark, the binding rule in Ireland continued indefinitely. Members took several legal cases against co-operative societies on the grounds that the rule unfairly tied them into a contract with the co-operative. ${ }^{87}$ In 1919, the most significant legal action taken against Ballymacelligott Cooperative Society by Richard McEllistrim saw private rivals successfully overturn this binding rule.

Ballymacelligott in County Kerry was home to a thriving co-operative society that expanded its operations during the war. In 1912, the society possessed two creameries with an annual turnover of $£ 8,000$. By November 1920, it operated four creameries with a turnover of $£ 58,500$. In 1916 , the committee called a special meeting of members and adopted the binding rule. The society later used the regulation to penalise a member, Richard McEllistrim, because he supplied milk to a creamery run by J.M. Slattery and Sons. However, the roots of this legal conflict partly lay in the fact that local kinship networks helped to govern the local economic distribution of milk supplies. According to Ballymacelligott's manager, John Byrne:

The non-Co-operative Society ... got ... McEllistrim (whose sons they had employed as managers in their concern) to bring an action against this society to declare the rules invalid as in restraint of trade. ${ }^{88}$

Slattery and Sons wanted to entice the milk suppliers who frequented the cooperative creamery to their own premises and McEllistrim's decision to break 
the binding rule served their purpose. Aided by Slattery, McEllistrim brought his case to trial, which reached the House of Lords in early 1919.

The IAOS recognised the threat posed by this legal action and promised to pay for Ballymacelligott Society's defence. Although a local affair, the case became a test of the national movement's ability to withstand an assault on its position by the private sector. The outcome of the case held the potential to undermine the industry's future development. A majority decision found in favour of McEllistrim on the grounds that the binding rule imposed 'restrictions further than were reasonably necessary for the protection of the society, the rules were unenforceable as being in unreasonable restraint of trade'. The only dissenter, Lord Parmoor, argued that the contract between a co-operative society and its members possessed a 'distinctive character' whereby 'business can be instituted and carried on in a co-operative basis' ${ }^{89}$ Parmoor's words offered little comfort. The IAOS suffered a heavy financial loss of $£ 3,850$ and appealed to members in their newspaper for financial help as they fought the case 'in the interests of the movement' against 'a powerful and well-organised trade combination' ${ }^{\text {'90 }}$ (see figure 5.1). The creamery business remained the IAOS's largest asset, but its position appeared much more vulnerable after the McEllistrim verdict.

\section{The general purpose society}

Despite the mixed outlook facing the dairy sector after 1919, in the field of co-operative retail and distribution the IAOS held great hopes that a breakthrough might occur after the war. The increased cost of living associated with the war brought the issue of rural consumption into focus. Co-operative agricultural societies allowed farmers to jointly purchase goods and machinery at wholesale prices and therefore cheaper than from traders. The IAOS viewed agricultural societies as necessary for the diffusion of new agricultural machinery, but growth in this sector proved disappointing before $1914 .{ }^{91}$ In 1897, the Irish Agricultural Wholesale Society (IAWS) was founded as a trading federation to carry a range of retail and wholesale work for other co-operative societies. Individual agricultural societies could subscribe to the IAWS in order to provide the trade body with substantial capital that allowed the larger body to pass on significant savings to members through the mass purchase of seeds, fertilisers and machinery. Importantly, as a separate organisation the IAWS could help agricultural co-operative societies develop a limited retail business after the Development Commissioners prevented the IAOS from performing this function. ${ }^{92}$ Therefore, the fact that all types of co-operative societies could federate to the IAWS allowed producer co-operatives to expand their businesses during the war. The number of co-operatives that affiliated to the IAWS increased from 188 in 1914 to 379 by the end of $1918 .^{93}$

Agricultural co-operative societies increased economic output by 160 per cent during the war as they diversified their services (see table 5.1). The more expansive activity conducted by agricultural societies during the war 'brought 


\section{Irish Agricultural \\ Organisation \\ Socicty.}

\section{Legal Defence and Indemnity Fund}

\section{McEllistrim v. Ballymacelligott.}

On the 6th of June the members of the L.A.O.S. Office and Finance ScbCommittee issued a letter to all the Societies in the movement asking them to contribute to a fund to defray the very heavy costs in this case, which have all fallen on the I.A.O.S., and to form the nucleus of a permanent legal defence fund which would provide money necessary for defending the movement against the astacks of its enemies. All co-operators must be well aware of the result of the case of McEllistrim v. the Ballymacelligott Society in which the Judgment of the Irish Court of Appeal was revised by the House of Lords. They may not be aware that the total costs in this case amounted to several thousands of pounds, and that it would have been just as impossible for the Plaintiff to have brought the case to that final and costly tribunal as for the Ballymacelligott Society to do so.

The I.A.O.S. raised funds to fight the case to a finish in the interests of the movement, and did so openly. The Plaintiff's backers, on the contrary, hid their names behind that of $\mathrm{Mr}$. McEllistrim, and won a temporary victory.

LET THIS BE A WARNING TO THE WHOLE MOVEMENT. It is being assailed covertly by a powerful and well-organised trade combination whish, emboldened by this success, may, and probably will, bring other cases into the Courts. It is to defeat the tactics of this combination that a LEGAL A NDD INDEMNITY FUND has become a vital and urgent necessity. A large and of money will be required, but it can easily be raised if each Soeiety will contritute in accordance with its ability.

All contributions will be placed to a separate account : cheques should be made payable to the I.A.O.S. and marked "Legal Defence Fund."

\section{R. A. ANDERBON,}

The Plunkett House,

Secretary.

Merrion Square,

Dublin.

Figure 5.1 Advert for Ballymacelligott Legal Indemnity Fund 
home to farmers the necessity of complete control over their industry, and to agricultural labourers the vital importance of procuring the necessities of life on terms commensurate with their wages'. By 1920, 271 agricultural co-operative societies existed and the IAOS wanted these to become more diversified societies that expanded the co-operative principle into a whole new range of services for the rural consumer. ${ }^{94}$ The IAOS referred to these new agricultural societies as 'general purpose societies. ${ }^{95}$ The development of agrarian distribution represented one way in which the IAOS attempted to bring the apparent divergent interests of Irish producers and consumers closer together. By 1920, the IAOS optimistically claimed that 'the distributive movement has begun to capture rural Ireland'. The IAOS attributed this development to the spontaneous initiative of farmers and labourers and claimed the establishment of new agricultural societies proved 'the fixed decision of the people to "self-determine" their own economic destiny'. This recasting of the 'old "agricultural society" emerged when it was 'difficult to forecast the economic future of the country at such a time of stress and uncertainty'. The general purpose society represented the IAOS's attempt to link 'the success of farming ... with the spread both of agricultural and distributive co-operation'. ${ }^{96}$

The Catholic clergy within the IAOS viewed the general purpose society as a way to bridge the interests of consumers and producers. Fr Michael O'Flanagan supported the co-operative movement as a force for social, economic and moral progress. A lifelong advocate of agricultural co-operation and with a reputation as a Republican priest, O'Flanagan became a vice-president of the IAOS in 1919 and vice-president of Sinn Féin in 1920. As an advocate of Catholic social teachings, O'Flanagan saw economic co-operation as an effective way to resolve class conflicts between capital and labour and a means to treat each member of society with dignity and respect. In a pamphlet simply called Co-operation, O'Flanagan argued that all private companies failed to achieve this objective because they were organisations bound together through 'money, or capital'. The co-operative organisation sought 'a different and higher bond. Instead of a money link co-operation seeks to substitute a human link. Instead of building with the pound as unit, co-operation builds with the man as unit'. For O'Flanagan, cooperatives restored human dignity to economics through their mutual business organisation: 'the Co-operative Society has members where the Joint Stock Company has shareholders. ${ }^{97}$

A tension at the heart of the co-operative movement in Ireland related to the fact that it helped to bring class tensions about in a new guise that crudely pitted urban and rural citizens against one another. Fr O'Flanagan welcomed the introduction of the general purpose society because he wanted the IAOS to branch out into retail services. He argued that although co-operative retail had been attempted in Ireland, these efforts were conducted under great pressure. However, such a service was required because more than any other sector he 
believed that the 'great advantage of co-operative shopkeeping is that it is a very simple way of teaching people the rudiments of co-operation' ${ }^{98}$ Fr O'Flanagan believed if Irish co-operation could incorporate those consumers into the movement missed by the spread of creameries then the economic interests of farmers and labourers might be harmonised.

An example of pioneering work in this direction occurred in Rathmore, County Kerry. Rathmore's farmers established a general purpose society at the start of 1919, which combined a creamery and shop representing

one of the newer type of creameries which it is believed will be the general type in the future. It was organised with the object of undertaking the manufacture of dairy products and the supply of all the requirements of its members. ${ }^{99}$

The Great War saw an evolution away from single-function societies. In the immediate aftermath, the wider co-operative movement anticipated the establishment of more societies like Rathmore, which represented a significant leap forward in the extension of the IAOS throughout the economy. The IAOS hoped that 'the general purpose type of society of which Rathmore is an example, promises much more success'. ${ }^{100}$

The movement celebrated Rathmore Co-operative Society's establishment with fanfare. A ballad written by the Bard of Rathmore and published in the Irish Homestead conflated Home Rule with the economic liberation of co-operation and equated farmers' control over their industry through the co-operative as a victory over landlords and exploitative dealers.

Home Rule is coming to Erin's shore,

And home industry to sweet Rathmore,

The Farmers' Factory will shortly crown,

Our handsome rising Blackwater town ...

The landlords reigned, but their day did come,

So the proud fat dealers today are dumb,

For the farmer rises now with a smile,

Who forces bread from his native soil.

Sure we all have shade from the farmers' wing,

He feeds the tramp, and he feeds the King,

He steers the ship, and he runs the train,

And he wins the battle fought on the plain ...

So no more we'll pay for our goods too high,

But the best of stuff at low prices buy,

Down with high prices for evermore,

And up the farmers, and up Rathmore. ${ }^{101}$

It also pre-empted the application of Home Rule. The ballad identified the farmer as the foundation stone of the Irish nation and emphasised that agriculture underpinned the whole social structure. 
Rathmore Co-operative Society registered for business on 6 May 1919 and led one local inhabitant to describe the enterprise as 'the shopping and social centre of east Kerry and part of West Cork' ${ }^{102}$ Charles Riddall assured the IAOS that the society's prospects looked good. The society operated a creamery, but its main objective saw it 'engage very largely in a general store trade'. The society attracted support from 'all members without distinction [who] are extremely keen'. Rathmore remained untouched by the co-operative movement up to this point, but its varied business operations offered the potential to attract local members. The area was covered in small farms and most of the butter made in the district was produced within the home. The society's establishment encouraged the adoption of modern dairy techniques by opening a creamery, but also appealed to conservative inhabitants by selling local homemade butter through the cooperative store. The management hoped that the prices paid for creamery butter would encourage the conversion of local agriculturalists into modern co-operative dairy farmers. Before it opened, the society acquired 70 members who bought 1,000 shares. ${ }^{103}$ This expanded to 208 members by July. Despite Riddall's early optimism, opposition soon emerged. Another organiser reported at the end of July that the creamery competed for local milk with the Lakelands Dairy Company, while because the society operated a shop, 'the local shop-keepers are offering all the opposition they can to the project'. ${ }^{104}$

The establishment of Rathmore Co-operative Society once more revealed the importance of IAOS organisers. Charles Riddall provided advice on hiring employees and a manager, and placed the IAOS's official accountancy services at Rathmore's disposal. ${ }^{105}$ James Fant offered his services during the construction of the society's premises. However, the committee sometimes ignored his advice, which led Fant to describe Rathmore's building progress as 'slow and disappointing' ${ }^{106}$ The appointment of a new manager in August 1920 saw increased collaboration between the society and the IAOS. With someone in place to act as a fixed point of contact Fant helped with the acquisition of new creamery machinery and offered precise instructions for its installation. ${ }^{107}$ At the start of 1921, Rathmore's creamery finally opened alongside the shop trade already ongoing.

The IAOS believed the general purpose societies provided an opportunity to capture new members and epitomised the movement's 'most representative type of institution'. The general-purpose society like that at Rathmore, sought to create a union of interest 'not merely between persons of varying political and religious beliefs, but between farmer and labourer, producer and consumer, countryman and townsman'. A period of renewed, popular enthusiasm about co-operation beckoned. At the IAOS annual conference in 1920, delegates commended the Dáil's enthusiasm for co-operation and welcomed the fact that a cross-section of 'political opinion in Ireland ... accepted the co-operative movement as a recognised ... element in national welfare'. ${ }^{108}$ However, these new developments occurred against a backdrop of violence and unrest. At the very point that a new 
phase of co-operation looked set to occur, co-operative societies found themselves targets of state-sponsored violence and the site of political and social tensions that derailed this progress.

\section{The Irish co-operative movement and the Irish War of Independence}

Frantz Fanon described decolonisation as 'always a violent phenomenon' and this captures something of the Irish experience during 1920 and $1921 .{ }^{109}$ Confrontations between the IRA and Crown forces, made up of the Royal Irish Constabulary, Auxiliaries and the Black and Tans, ${ }^{110}$ took place with increased intensity as the government applied a military deterrent as part of its security policy. ${ }^{11}$ Guerrilla warfare, raids on private property, martial law, industrial strike action and the spread of terror dominated news stories about Ireland from 1919 until the announcement of a truce in July $1921 .{ }^{112}$ Pat 'the Cope' Gallagher, President of Templecrone Co-operative Society, recalled that 'the Black and Tans were worse than savages let loose. They were murdering, ravishing and burning. ${ }^{113}$ Much of the violence occurred in rural areas with a particular concentration in the south-west and the centre of the dairying industry. ${ }^{114}$ Violence disrupted social and economic life throughout the country and co-operatives found themselves on the receiving end of state violence in the most serious threat to the movement yet.

The decision to target co-operatives formed a central component of British government's security policy. During 1920 and the first half of 1921, co-operative societies across the country were attacked by Crown forces. By 1 January 1921, 42 co-operative societies suffered severe damage to premises, and in some cases complete destruction. Robert Anderson claimed that each creamery destroyed put 800 farmers out of business. ${ }^{115}$ Violence placed severe strain on the movement, with local societies forced to close and national resources stretched to breaking point. Security forces responded to IRA provocation through attacks on co-operative societies as a way to punish a community. The British government's recruitment of ex-servicemen as police auxiliaries provided the main perpetrators of violence. Attacks on co-operatives occurred as an act of reprisal after an IRA attack in an area, but also reflected a lack of discipline among this new police force. ${ }^{116}$ In the short term, violence disrupted the working lives of farmers in the area, but in the longer term the economic capacities of co-operative societies experienced irreversible setbacks.

Throughout 1920 and 1921 IAOS staff received regular updates about assaults on co-operative societies. One such incident was carried out by a party of men on the night of 23 October 1920. The men travelled to the creamery in a police vehicle and stopped at a house in the townland of Ballydonoghue where they assaulted two young men and 'bobbed the hair of two girls'. When they arrived at the creamery 'they burned down a large part of the Co-operative Creamery, destroying machinery, a large quantity of cheese, and $£ 1,000$ worth of butter'. 
Estimated damage to the society stood between $£ 10,000$ and $£ 12,000 .{ }^{117}$ Several days later another attack occurred less than six miles away at Abbeydorney Cooperative Society carried out by ' 3 lorries of armed men, some wearing khaki, and the majority [Royal Irish Constabulary] uniforms'. These men set fire to the creamery, caused $£ 2,000$ of damage, and looted stocks of butter and cheese. ${ }^{118}$

The result of these attacks placed affected co-operative societies on the brink of collapse and the IAOS provided a vital source of support. Organisers responded to calls for assistance from co-operative committees, which helped to reaffirm and strengthen the connection between individual societies and the national body. For example, Rattoo Co-operative Society based in a district of good dairy land in north Kerry let its IAOS affiliation expire during the war and ceased payment of the subscription fee. Charles Riddall informed Dublin in late 1919 that 'there is no bothering about this Society [Rattoo] for the present. No doubt they will return to the fold as so many other Societies have done. ${ }^{119}$ In November 1920, as news of attacks upon neighbouring societies filtered through, the IAOS leadership wired Rattoo Co-operative Society to ascertain news concerning its position. Rattoo replied: 'this creamery is not interfered with so far, \& we are now hopeful it will escape for the present'. ${ }^{120}$ Rattoo remained unharmed, but the IAOS's work in this period convinced the committee to renew its affiliation. In particular, the society's committee appreciated the publicity work carried out by Plunkett and $Æ$ on behalf of the movement, and pledged a special subscription of 'funds for carrying on the campaign in Great Britain against the destruction of Societies' ${ }^{121}$ Rattoo Co-operative Society received the assurance of support from organisers if an attack occurred in return.

Violence aimed at co-operatives undermined British legitimacy in Ireland and forced the IAOS to abandon any pretence of a non-political position with regard to the government's policy. Horace Plunkett instigated a publicity campaign across Britain in which he highlighted the repressive tactics for a British audience. In September 1920, he wrote to The Times in protest against reprisals carried out against creameries. In an appeal to readers, Plunkett stated that he 'would not drag the Irish Agricultural Cooperative Movement into the Anglo-Irish controversy at its acutest stage without compelling reasons'. However, the network of trust built up disintegrated overnight as farmers refused to deal with co-operative businesses 'because they believe that these are specially marked out as objects of reprisal by the guardians of the law'. ${ }^{122}$ The attacks damaged more than bricks and mortar; they wrecked the bond between farmers and their societies that had been hard won over previous years.

David Lloyd George, the Prime Minister, responded to Plunkett's intervention when he delivered a speech at Carnarvon, Wales, on 9 October 1920. The speech formed a defence of the government's Irish policy and overseas news agencies covered its content. He rejected demands to grant Ireland dominion-status Home Rule, which would have included Irish political control over their own military 
and naval bases. Furthermore, Lloyd George defended the violent behaviour of the police and military to suppress rebellious activity in Ireland. The main targets of Lloyd George's speech were critics from within his Liberal Party, but he aimed specific jibes at Horace Plunkett. Lloyd George ridiculed Plunkett's attempt to represent any serious opinion on the Irish Question and he joked that 'Sir Horace Plunkett ... cannot even speak for his creameries'. ${ }^{123}$ Despite this attempt to deflect attention on to Plunket's political credibility, the plight of the Irish cooperatives remained newsworthy and continued to embarrass Lloyd George's Coalition Government.

Æ also pursued a publicity campaign aimed at the British public. ${ }^{124}$ In 1920, he published $A$ Plea for Justice, which called for a public inquiry into the attacks by ' $[t]$ he armed forces of the Crown ... [who] burned down factories, creameries, mills stores, barns and private-dwelling houses'. Æ understood the rationale behind these attacks as a punitive response calculated to lead 'to the wrecking of any enterprise in the neighbourhood the destruction of which would inflict widespread injury and hurt the interests of the greatest number of people'. ${ }^{125}$ The publicity campaign attracted influential support within Britain and drew attention to grim realities in Ireland. In particular, the Manchester Guardian reported on the breakdown of law and order in the Irish countryside. Headlines such as 'The Burning of Irish Creameries', 'Outrages in Co. Kerry' and 'Blow to the Co-operative Movement: Farmers Punished for Work of IRA' characterised that paper's reportage of the Irish situation. ${ }^{126}$

This effect of such publicity work encouraged criticism of the government from a non-Irish perspective. The British Labour Party sent an investigative commission to Ireland in November 1920 to consider the case for Irish freedom and its concern over the degradation which the British people are now suffering in consequence of the policy of repression and coercion which has been carried out in its name. ${ }^{127}$ The Commission visited areas affected by violence in order to interview witnesses and provide an alternative narrative of the effects of British policy in Ireland than that offered by Lloyd George's government. As part of this fact-finding mission the Commission interviewed Robert Anderson, Æ and Paul Gregan of the IAOS, along with managers of victimised co-operative creameries 'who gave evidence on the economic hardships created by the wrecking of the machinery, plant, and buildings'. ${ }^{128}$

The British Labour Party criticised the government's policy in Ireland as counterproductive. The IRA's success resided in the fact it enjoyed popular support within communities and the actions taken by Crown forces exacerbated a volatile situation. The subsequent report confirmed the arguments of Plunkett and $Æ$ that British security forces targeted civilian businesses in response to local guerrilla activity. These attacks aimed to 'cause the maximum economic and industrial loss to an Irish countryside or city' and that these 'reprisals have been scientifically 
carried out' (emphasis added). The policing tactics of the Crown force represented not so much a spontaneous reaction to local violence, but a calculated attempt to subdue the local population. Moreover, the Labour Commission argued that the IRA ultimately benefited from the military reprisal policy as the 'destruction of creameries and manufactories only serves to stimulate recruiting by increasing the number of desperate men'. ${ }^{129}$ The destruction of co-operative businesses increased the unpopularity of the British state in Ireland and weakened the moral case for the government's Irish policy.

British co-operators also rallied to the IAOS's support in a sign that relations between the two movements had improved. Frequent articles in the Co-operative News, which reflected the official views of the movement in Britain, reported on the Irish situation and focused on outrages committed against Irish co-operators by Crown forces. The newspaper provided readers with detail on Plunkett's interventions and questioned the 'sanity' of the British Government that embarked upon a campaign to destroy the Irish movement. In a strong front page editorial, the Co-operative News' special correspondent called for an end to attacks on Irish creameries and stated firmly, 'if the Government is going to make war on co-operative establishments in any part of the British Isles, co-operative societies in the British Isles must accept the challenge and declare war upon the Government' ${ }^{130}$

Not all readers shared this sentiment. The publication of a controversial cartoon that depicted a British soldier wielding a bayonet and fiery torch as he rampaged towards an Irish home provoked a backlash from some readers. The cartoon was a reprint from the Catholic Herald entitled 'Those Creameries' (see figure 5.2). The character of a young boy named Young Erin asked: 'Does he ever stop?' The boy's mother replies: 'Didn't he stop for two minutes on Armistice Day?' A series of letters appeared in the next edition which protested against the 'gross representation of the British soldier' that adorned the front page of the paper. Despite the criticism, the editors maintained that the government continued to prevent people from learning the truth about the conduct of the police and army in Ireland. In that context the publication of the cartoon was an attempt to portray the 'feelings of the innocent victims of the present regime of force in Ireland' 131

Alongside the attempts to bring the Irish Question back into the focus of British media attention, the IAOS's organisers continued to place themselves in danger on many occasions. On 12 May 1921, the Chairman of Rathmore Cooperative Society notified Plunkett House of an attack by Crown forces that destroyed the society's shop and machinery four days before the scheduled opening of a new creamery. ${ }^{132}$ The attack occurred at a crucial point in the society's development and threatened to derail the co-operative project within the area. The IAOS despatched Nicholas O'Brien, who arrived 'after much inconvenience 


\section{THOSE CREAMERIES.}

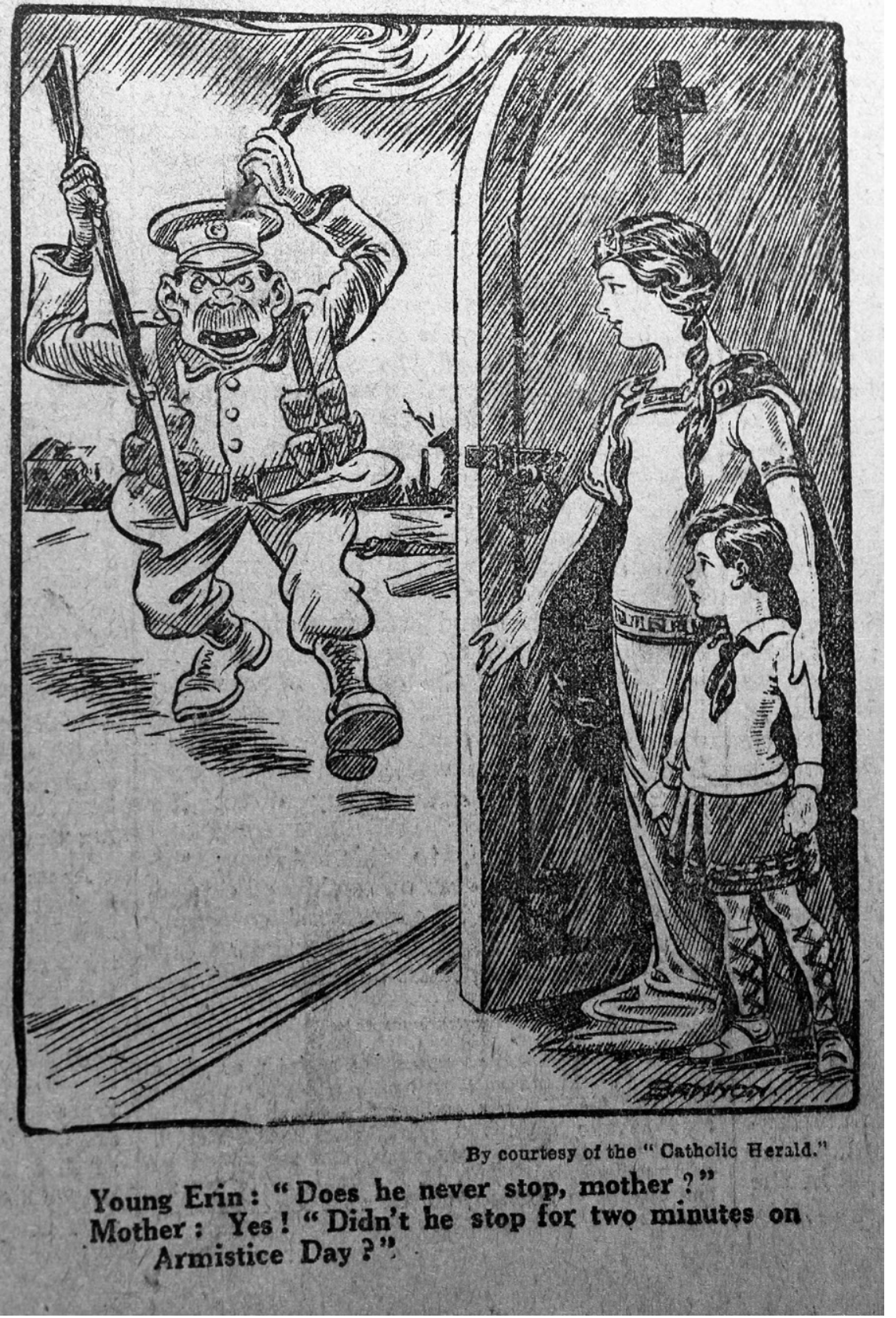

Figure 5.2 'Those Creameries' 
and personal risk'. Taxis refused to transport him to the district and he arrived a day later than scheduled on 31 May 1921. O'Brien's timing proved fortunate. He reported that on 30 May, the entire village 'was cleared out about 2 o'clock [a.m.] ... and had some other experiences also'. On visiting the society he noted that the 'building was completely destroyed, nothing but the walls stand and they too have suffered probably from bombs. The stocks in store were completely burned out.' O'Brien advised Rathmore's management to continue the store trade 'in an implement shed at the rear of the main building'. ${ }^{133}$

Fear undermined local solidarity around the co-operative society. The violent attacks upon co-operatives spread anxiety throughout the local population and trade suffered as a result. Thomas de Lacy, the manager of Rathmore Co-operative Society complained to James Fant that store business declined after the attack because 'the people are afraid to come in'. Local employment generated by the new society was also undermined. The committee implemented a cut in the manager's salary and released his assistant from employment. ${ }^{134}$ Widespread awareness of the fact that armed forces targeted co-operatives damaged the business of societies such as Rathmore. Local inhabitants refrained from utilising the co-operative store and the creamery remained closed during this time. Rathmore staggered into the 1920s struggling to re-summon the initial enthusiasm of local members lost to alternative shops and productive centres. Once considered the IAOS's flagship society, Rathmore's rapid decline told a depressing story for co-operators who wished to usher in a new phase of economic experimentation in distributive and retail services.

It was not only fledgling societies such as Rathmore that suffered permanent injury - so too did long-established co-operatives. Some, such as Ballymacelligott Co-operative Society, even experienced fatalities as staff and suppliers got caught up in the violence. On the morning of 12 November 1920, security forces attacked one of the creameries attached to Ballymacelligott Co-operative Society and, as a result, two men were killed and two others injured. According to witness statements, a lorry carrying police and military arrived at Ballydwyer creamery and as they jumped from the lorry some of the employees fled from the scene. A member of the local IRA brigade, Thomas McEllistrim, recalled that members of the Ballymacelligott Active Service Unit happened to be close to the creamery and as they 'made a dash for escape ... fire was opened on them immediately by Tans and RIC'. ${ }^{135}$ Another witness claimed that the people fired upon were 'suppliers and employees' to the creamery although one of the injured men, Jack McEllistrim, was an IRA volunteer. ${ }^{136}$ The two men who died were John McMahon, a farmer and member of the committee who had brought corn to the society's mill to be ground into flour, and Patrick Herlihy, employed as the dairyman at the creamery. The official version of events presented to the House of Commons by the Chief Secretary of Ireland, Sir Hamar Greenwood, claimed that 'about seventy armed men' fired at a party of journalists and their police escort from 
the local creamery. This 'act of war' justified the reprisal. The British Labour Party who sent representatives to investigate the story disputed this account as a 'caricature of what actually happened'. Their commission's inquiries into the Ballymacelligott attack instead concluded that no shots were fired from the creamery and 'none of the men who were killed or wounded were carrying arms ... [and] no arms or ammunition of any kind were found in the creamery'. The next afternoon a party of men approached the creamery from Castleisland and set fire to the premises. The perpetrators appeared not to be the military and those people who tried to rescue butter from the premises 'were prevented from doing do by the person who appears to have been in charge of the party. ${ }^{137}$ After the commission's visit to Ballymacelligott, Crown forces raided the house of the creamery manager and killed another two men found there. The Labour Commission described the whole incident 'as discreditable to the Government as any of the occurrences for which the Government or its agents have been responsible'. It concluded that no basis existed for the attack and called for an independent inquiry. $^{138}$

Rumours circulated that collusion between private creamery owners and the military encouraged the attacks on co-operatives. Robert Anderson discussed the events of Ballymacelligott with James Fant which he described 'as a result of a dead set made upon it by Crown forces, at the instance, to some extent I believe at least, of local creamery proprietors'. ${ }^{139}$ A sworn witness statement provided by Ballymacelligott's manager, John Byrne, linked the attacks to recent court cases with Richard McEllistrim. Byrne accused agents of Slattery's creameries of spreading:

false and malicious reports concerning me and members of the Co-operative Society with a view to undermine the loyalty of the members [and] ... to set the forces of the Crown against the Staff and members of the Committee of the Co-operative Society. I regret to say and I charge that these false and malicious reports have been accepted and acted upon by the forces of the Crown. I was arrested in 1916 and interned for 3 months without charge or trial. The trade and business of the Society suffered as a consequence.

The attacks of 12 and 13 November halted production at the society and resulted in the development whereby 'a number of the members have gone over to the Non-Co-operative concern'. ${ }^{140}$ This concern in question was J.M. Slattery and Sons, which showed that local rivalries remained a live issue in the area. Competition between private and co-operative creameries intensified once again under the cover of violence, which provided the movement's rivals with opportunities to capitalise. Suggestions of collaboration between private creamery owners and security forces arose out of this situation and created an impression that the War of Independence provided cover for private creameries to extend their own interests. 
In February 1921, the Manchester Guardian described the effect of British policy as heralding 'the economic decay of Ireland':

the burning of creameries, the destruction of farmsteads ... the withdrawal of labour from the land, through imprisonment or outlawery, the stoppage of co-operative organisation are steadily depreciating the productivity of Irish agriculture. ${ }^{141}$

Later that year crown forces modified their reprisal tactics to close down businesses instead of carrying out attacks. The cost of closures and interruptions proved high and placed financial stress upon a society's resources. The solicitor who represented Ardfert Co-operative Society detailed the outrage at his client's premises in an account prepared for the Kerry County Council office in pursuit of a compensation claim a year later:

On March the 21st 1921 at Ardfert Crown Forces surrounded the Creamery and ordered the Staff to go out. The Staff were detained for a week in a 'round up' and when they returned, butter to the value of $£ 625.10 .0$ was stolen, cream to the value of $£ 200$ had gone waste as had also the Cream in two Auxiliary Creameries to the value of $£ 800$. Wages for week $£ 14$, Consequential loss $£ 1,200$, Llyod's [sic] Insurance, Riot and Civil Commotion $£ 300$, Mare shot dead and consequential loss $£ 97.0 .0$ - Claim: $£ 3236.10 .0$. $^{142}$

The differential treatment of co-operative and proprietary creameries by the military led to a further deterioration in the relations between the two sectors. The Manchester Guardian reported that 'a number of creameries in the South of Ireland have been closed by order of the military'. These tactics rendered stocks held at co-operative societies 'useless for the time being, and the effect of the order ... is to harm the country people as much as possible'. ${ }^{143}$ Once again, the military's orders disproportionately affected the co-operative sector. The military closed down a creamery at Kilflynn operated by Abbeydorney Co-operative Society while local private creameries continued to trade. Abbeydorney's manager wrote to his brother after the creamery's closure, 'the funny thing is that Slattery's Creamery, which is within a stone throw of ours, was not closed at all, with the result, that a large number of our suppliers have gone to them'. ${ }^{144} \mathrm{~A}$ few nights later, the military ordered Slattery's creamery to close temporarily, but they reopened once again on 9 June. In stark contrast, Abbeydorney Co-operative Society's Kilflynn premises remained shut. Nevertheless, the society's membership decided to reopen without permission 'and let the military do what they wished'. The result of this decision saw their machinery sabotaged by unidentified raiders after only one day of trading. ${ }^{145}$ Nicholas O'Brien sent his assessment of these events to Robert Anderson:

It is regretable $[s i c]$ that local friction should cause any further trouble, but I fear that the interests of proprietary creamery owners in Co. Kerry have 
been the cause of much damage to co-operative property. Of course there has been no definite proof of this, but there is a strong feeling that this is the case, as proprietors have not suffered near as much as co-operatively owned creameries ... I hope that when matters settle, if they ever do, we may be able to remedy much of this ill feeling by making an effort to wipe out proprietary opposition. ${ }^{146}$

Organisers who worked in areas where attacks occurred suspected collaboration between private creamery owners and Crown forces. In a handwritten note attached to the report, James Fant commented on O'Brien's analysis, writing that the 'feeling expressed above is well founded and people in Tralee and district are fully aware of the reasons for the "glove" treatment accorded to certain proprietary creameries' ${ }^{147}$ What is clear is that reprisal tactics rekindled socioeconomic tensions between co-operative and private creameries that had remained dormant during the First World War.

\section{The truce, July-December 1921}

British security forces continued to apply their reprisal policy with increased desperation until the announcement of the truce on 11 July 1921. The Truce came as a relief for a population wearied by conflict and violence. The prospect of resolution led to a cessation in the fighting between Republicans and Crown forces, but uncertainty about what might happen next led to a period of political confusion. The negotiation of the Anglo-Irish Treaty between the British government and a Sinn Féin delegation led by Arthur Griffith and Michael Collins dominated the news that autumn and winter. The agreement signed on 6 December 1921 culminated in the establishment of the Irish Free State made up of the 26 southern counties of Ireland in 1922. The British sovereign remained the head of state and six north-eastern counties remained a separate Northern Ireland. Republicans in the Sinn Fein movement split over whether they viewed approval of the Treaty as an acceptable compromise or a betrayal of national aspirations. ${ }^{148}$

Before that and during the uncertain months of late 1921, the Truce period provided respite for struggling co-operative societies as attention turned to the immediate work of reconstruction. The co-operative movement's recovery depended upon the loyalty of local members combined with the guidance of the IAOS. Larger and long-established co-operative creameries demonstrated their resilience during these months. Ballymacelligott Society, which lost its central creamery, directed milk supplies to auxiliary creameries based in the neighbouring villages of Gortatlea and Polatty. Ownership of auxiliary creameries allowed larger cooperative creameries to recover more quickly as they were able to restart tentative production. The manager's fear that members would switch their allegiances to rivals proved inaccurate. John Jones, Ballymacelligott Society's president, informed 
Robert Anderson that the 'loyalty of the Society's members is to be commended through all the harassing ... their determination not to be beaten down was inspiring'. Jones thanked the IAOS for their support during the months that followed the attack in November 1920 and added its work 'will not be forgotten by the people of Ballymacelligott for many a day'. ${ }^{149}$

The publicity generated around the co-operative attacks elicited sympathy for Ireland overseas. In America, fundraising efforts got under way with the establishment of a loan fund to aid the affected co-operative societies. The American Committee for Relief in Ireland was organised in New York after a report by a delegation of the American Society of Friends sent to Ireland in February 1921. The delegation investigated 'economic distress in Ireland, [and] ... has not been equalled in scope by any other investigative body, either Irish, British, American, or of any other nationality'. An estimated 25,000 families required relief and due to the 'crippling of the co-operative creameries in Ireland, 15,000 farmers ... are suffering severe loss and are faced with even more deeply serious distress in the immediate future'. ${ }^{150}$ A special creamery expert travelled with the travelling party to 'give special attention to the destroyed creameries ... [and help] rehabilitate an essential industry'. ${ }^{151}$ The Irish White Cross emerged out of the delegation's report. Based in Ireland and managed by the Dublin Quaker, James G. Douglas, the White Cross was 'an Irish organisation, independent of any religious and political body ... [that administered] funds either for immediate relief or for reconstruction'. ${ }^{152}$ The White Cross provided the loan capital required to rebuild creameries and replace broken machinery. Injured co-operatives sought this loan capital to restart business as soon as possible and the IAOS lobbied on their behalf. ${ }^{153}$ For example, the IAOS secured a White Cross loan worth $£ 2,500$ to stabilise Ballymacelligott Co-operative Society and with little pressure to repay 'any of the White Cross money until it is quite convenient for the society to repay it'. ${ }^{154}$

Less well-established societies experienced painful reconstructions and lost their positions in the community. In Rathmore, economic opponents frustrated the recovery of the co-operative society. When the White Cross launched a fundraising drive in the area, they met with local opposition when its people learned the funds would help replenish the local co-operative. For example, the application to the White Cross by the Rathmore Co-operative Society reignited dormant tensions. The manager of Rathmore Co-operative Society, Thomas de Lacy, wrote to Charles Riddall explaining: 'there is ... bitter opposition to the Coop here, as a matter of fact two Traders who collected the village for White Cross have refused to hand up the subscriptions when they heard [the] Creamery had applied for loan'. ${ }^{155}$

The IAOS placed great emphasis upon the reconstruction of Rathmore Cooperative Society. In August, James Fant visited the village and reported that the 
society required urgent financial aid. The reconstruction of the society would be a crucial step in the reinvigoration of the area and:

would form the centre of a local industry much needed in the locality to aid and develop dairying and allied agricultural industries - the only source of income [for] hundreds of small farms and others in this district where much of this land is reclaimed bog and mountain land ... Knowing the efforts that these people have made to establish their creamery the amount of local free labour by horse and man that has been given and their efforts to help themselves I would specially request the fullest application for financial aid to give them a fresh start. $^{156}$

The priority in the society's reconstruction was given to the creamery business as dairying offered the most likely source of income for farmers.

A society like Rathmore faced another problem different to that affecting a creamery society like Ballymacelligott. The attack upon the shop meant a loss of stock and capital and the longer it remained closed the more local enthusiasm for the new society decreased. Initially, the store business suffered because locals feared being caught up in further reprisals. Weekly turnover at the shop was $£ 300$, before the attack in May 1921. By October, this figure dropped to $£ 120$ and outstanding debts due from members totalled $£ 1,100 .{ }^{157}$ In Nicholas O’Brien's assessment, 'the store trade has fallen away considerably and I believe that unless something is done ... the store business will dwindle away altogether'. ${ }^{158}$ By the end of 1921, the local population appeared to have returned to other shops to purchase their goods once again. Rathmore Co-operative Society limped through the next decade harried by problems before it passed into the receivership of a semi-state body, the Dairy Disposal Company (DDC), in 1930. By 1936, a DDC employee recommended the dissolution of Rathmore Co-operative Society, describing it and others like it as, 'to all intents and purposes failures'. ${ }^{159}$ The general purpose society receded on the list of IAOS priorities as it looked to rebuild its creameries and capture the attention of an incoming Irish administration. The IAOS focused again upon the interests of the producer and the efforts to harmonise these interests with the consumer declined.

Over the course of the next few years, the task of stabilising and rebuilding co-operative societies preoccupied IAOS employees. Their recovery faced further challenges as the post-war period slid into a global recession, resulting in a depressed market for agricultural produce. National economic success depended on the ability of co-operative societies to maintain production in underdeveloped districts to effect change. In districts like Rathmore, where traditional and inefficient methods of production persisted and agricultural holdings were poor, co-operative institutions encouraged economic improvement and revitalised living conditions. However, opposition to co-operative societies in the form of private creameries and traders reasserted their position in the rural economy during 1919-21. The 
access granted to charitable loan capital enabled co-operatives to meet these challenges.

As Ireland prepared for independence, the movement reflected upon a period in which severe damage was inflicted on co-operative property and the lives of members and employees were threatened. The experience of those years immediately after the war meant that:

The whole rural population in several districts had to carry on life under conditions that were ... discouraging and frequently full of risk both to themselves and to their industry. ${ }^{160}$

Despite the violence, the movement emerged from its darkest period yet and the IAOS could assert that 'no stronger proof of the inherent vitality of the movement has ever been recorded'. ${ }^{161}$ Nevertheless, violence exacted a heavy price. The survival of the movement through a moment of violent crisis reflected an adherence to co-operative organisation among the rural population. Many, although not all, people in rural areas rallied to the support of these societies ensuring they remained key players in national development. As political independence arrived, the co-operative movement looked to ensure that aspects of a Co-operative Commonwealth underpinned the new Irish Free State.

\section{Notes}

1 R.F. Foster, Modern Ireland, 1600-1972 (London: Penguin, 1989), 495; J.J. Lee, Ireland, 1912-1985: Politics and Society (Cambridge: Cambridge University Press, 1989), 40.

2 Ronan Fanning, Fatal Path: British Government and Irish Revolution, 1910-1922 (London: Faber \& Faber, 2013).

3 Dáil Éireann, 'Democratic Programme of Dáil Éireann', Parliamentary Debates, Volume 1, 21 January 1919, http://oireachtasdebates.oireachtas.ie/debates\%20authoring/ debateswebpack.nsf/takes/dail19190121000161 [accessed 17 September 2017].

4 Arthur Mitchell, Revolutionary Government in Ireland: Dáil Éireann, 1919-1922 (Dublin: Gill \& Macmillan, 1995), 43.

5 Brian Farrell, The Founding of Dáil Éireann: Parliament and Nation Building (Dublin: Gill \& Macmillan, 1971), 80.

6 David Fitzpatrick, The Two Irelands, 1912-1939 (Oxford: Oxford University Press, 1998).

7 Michael Laffan, The Resurrection of Ireland: The Sinn Féin Party, 1916-1923 (Cambridge: Cambridge University Press, 1999), 315. Also Joost Augusteijn (ed.), The Irish Revolution, 1913-1923 (Houndmills, Basingstoke: Palgrave, 2002); John M. Regan and Mike Cronin, 'Introduction: Ireland and the Politics of Independence, 1922-49: New Perspectives and Re-considerations', in Ireland: The Politics of Independence, 1922-49, ed. by Mike Cronin and John M. Regan (Basingstoke: Macmillan, 2000), $1-12$. 
8 David Fitzpatrick, Politics and Irish Life, 1913-1921: Provincial Experience of War and Revolution (Dublin: Gill \& Macmillan, 1977); Emmet O'Connor, Syndicalism in Ireland, 1917-1923 (Cork: Cork University Press, 1988).

9 Fergus Campbell, Land and Revolution: Nationalist Politics in the West of Ireland, 1891-1921 (Oxford: Oxford University Press, 2005).

10 Ruth Russell, What's the Matter with Ireland? (New York: The Devin-Adair Co., 1920), 13-14.

11 Russell, What's the Matter, 102.

12 Russell, What's the Matter, 107.

13 Russell, What's the Matter, 107-109.

14 Trevor West, 'Gallagher, Patrick', in Oxford Dictionary of National Biography, www.oxforddnb.com/view/article/65846?docPos=2 [accessed 14 August 2013].

15 Patrick Gallagher (Paddy the Cope), My Story, rev. edn (Dungloe: Templecrone Co-operative Society, n.d.), 173.

16 Russell, What's the Matter, 115-123.

17 Ibrahim Rashad, An Egyptian in Ireland (n.a.: privately printed, 1920), 2-3.

18 Mitchell, Revolutionary Government, 45.

19 William Murphy, 'Figgis, Darrell', in Dictionary of Irish Biography: From Earliest Times to the Year 2002, Volume 3, ed. by James McGuire and James Quinn (Cambridge: Cambridge University Press, 2009), 775-777.

20 Darrell Figgis, George W. Russell: A Study of a Man and a Nation (New York: Dodd, Mead and Company, 1916), 134.

21 Darrell Figgis, The Gaelic State in the Past and Future or 'The Crown of the Nation' (Dublin: Maunsel \& Co. Ltd, 1917), 53.

22 Aodh de Blacam, 'Æ as I Knew Him', Irish Monthly, 63.747 (1935), 606-613.

23 Diarmaid Ferriter, The Transformation of Ireland, 1900-2000 (London: Profile Books, 2005), 195.

24 Tom Garvin, The Evolution of Irish Nationalist Politics (Dublin: Gill \& Macmillan, 1981), 100-113; Tom Garvin, Nationalist Revolutionaries in Ireland, 1858-1928 (Oxford: Oxford University Press, 1987), 33-56.

25 Aodh de Blacam, Towards the Republic: A Study of New Ireland's Social and Political Aims (Dublin: T. Kiersey, 1918); Aodh de Blacam, What Sinn Féin Stands For: The Irish Republican Movement: Its History, Aims and Ideals Examined as to Their Significance to the World (Dublin: Mellifont Press Limited, 1921).

26 De Blacam, Towards the Republic, 26-27.

27 De Blacam, What Sinn Féin Stands For, 151.

28 De Blacam, Towards the Republic, 27-28.

29 P.J. Mathews, Revival: The Abbey Theatre, Sinn Féin, the Gaelic League and the Cooperative Movement (Cork: Cork University Press, 2003), 31.

30 De Blacam, Towards the Republic, 27-28.

31 Sinn Féin, Letter to Various Cumanns on Prospects of Co-operative Societies in Ireland (Dublin: Sinn Féin, 1919).

32 Michael Collins, The Path to Freedom (Dublin: Talbot Press, 1922), 133.

33 Arthur Griffith, The Resurrection of Hungary: A Parallel for Ireland with Appendices on Pitt's Policy and Sinn Féin, 3rd edn (Dublin: Whelan and Son, 1918), 141. 
34 'The Co-operative Commonwealth', Irish Homestead, 12 April 1919, 251.

35 Blythe quoted in, Mitchell, Revolutionary Government, 47.

36 Patrick Buckley, 'Blythe, Ernest (de Blaghd, Earnán)', in Dictionary of Irish Biography: From Earliest Times to the Year 2002, Volume 1, ed. by James McGuire and James Quinn (Cambridge: Cambridge University Press, 2009), 616-624 (p. 616).

37 Mitchell, Revolutionary Government, 47-48.

38 IAOS, Annual Report, 1919, 2-3.

39 IAOS, Annual Report, 1921, 2-3.

40 Mitchell, Revolutionary Government, 48-49.

41 Barbara Lewis Solow, The Land Question and the Irish Economy (Cambridge Mass.: Harvard University Press, 1971),192-193; Michael Wheatley, Nationalism and the Irish Party: Provincial Ireland, 1910-1916 (Oxford: Oxford University Press, 2004), chapter 2 .

42 Fergus Campbell and Kevin O'Shiel, 'The Last Land War? Kevin O’Shiel's Memoir of the Irish Revolution (1916-1921)', Archivium Hibernicum, 57 (2003), 155-200 (pp. 172-173).

43 E.J. Riordan, Modern Irish Trade and Industry (New York: E.P. Dutton and Company, 1920), 259.

44 Ernest Blythe, 'National Land Bank', Dáil Eireann Debates, Volume 16.21, 20 July 1926, http://oireachtasdebates.oireachtas.ie/debates\%20authoring/debateswebpack.nsf/ takes/dail1926072000039?opendocument. [accessed 8 June 2018].

45 'Sir Lionel Smith-Gordon', The Times, 9 December 1976, 16.

46 'Titled Englishman, Dublin Banker, Spends Week Here', The Evening Independent [St Petersburg, Florida], 14 January 1924.

47 Riordan, Trade and Industry, 260.

48 St. John Ervine, 'Ulster and Sinn Féin' The Times, 7 September 1921, 6.

49 Lionel Smith-Gordon, 'Nationality and Sinn Féin', The Times, 12 September 1921, 9.

50 L. Smith-Gordon, The Place of Banking in the National Programme (Dublin: Cumann Léigheacht an Phobail, 1921), 12.

51 'The National Land Bank: Its Constitution and its Aims' (c.1921), 4, NLI P2282.

52 IAOS, Annual Report, 1921, 23-24.

53 Smith-Gordon, The Place of Banking, 8-9.

54 Lionel Smith-Gordon, cited in Mitchell, Revolutionary Government, 89.

55 'Free State Banking Policy', The Times, 22 July 1926, 21.

56 Mary E. Daly, The First Department: A History of the Department of Agriculture (Dublin: Institute of Public Administration, 2002), 68-70; Mitchell, Revolutionary Government, 86-92.

57 Peggy Quinn, Des Aylmer, Donal Cantwell and Louis O'Connell, An Irish Banking Revolution (Dublin: Bank of Ireland, 1995), 16-22.

58 James Connolly, Labour in Ireland: Labour in Irish History; The Re-conquest of Ireland (Dublin: Maunsel \& Roberts Ltd, 1922), 320-321.

59 Connolly, Labour in Ireland, 327-328.

60 Thomas J Morrissey, Thomas A. Finlay, SJ, 1848-1940: Educationalist, Editor, Social Reformer (Dublin: Four Courts Press, 2004), 108-109. 
61 'Relief of the Starving', Co-operative News, 4 October 1913, 1302-1304.

62 'Close of the Dublin Relief Fund', Co-operative News, 28 February 1914, 260.

63 Keith Harding, 'The "Co-operative Commonwealth": Ireland, Larkin and the Daily Herald, in New Views of Co-operation, ed. by Stephen Yeo (London: Routledge, 1988), 88-107 (pp. 88-89).

64 Cited in Fitzpatrick, Politics and Irish Life, 210.

65 'Village Republics', Irish Homestead, 17 November 1917, 839.

66 'All Co-operators Now!', Irish Homestead, 29 March 1919, 204.

67 Henry Summerfield, That Myriad-Minded Man: A Biography of George William Russell ' $E$ ' 1867-1935 (Gerrards Cross, Bucks.: Colin Smythe, 1975), 191-192.

68 Cited in Ferriter, The Transformation of Ireland, 196.

69 ITGWU Return to Registrar of Friendly Societies 1917-25, NLI Ms. 27,034.

70 Dan Bradley, Farm Labourers: Irish Struggle, 1900-1976 (Belfast: Athol Books, 1988), 43-55.

71 Emmet O'Connor, A Labour History of Ireland, 1824-2000, 2nd edn (Dublin: University College Dublin Press, 2011), 106-107.

72 'Co-operation in Tralee', Irish Homestead, 30 November 1918, 792.

73 'Listowel Co-operative Store', Irish Homestead, 25 January 1919, 59.

74 'Warding Off Antagonism', Irish Homestead, 3 May 1919, 311.

75 Joseph Knapp, An Appraisement of Agricultural Co-operation in Ireland (Dublin: Stationery Office, 1964), 25.

76 IAOS, Annual Report, 1921, 7.

77 Bolger, The Irish Co-operative Movement, 210.

78 IAOS, Annual Report, 1920, 7.

79 Lionel Smith-Gordon, The Irish Milk Supply (Dublin: Co-operative Reference Library, 1919), 17.

80 'Mr H.T. Barrie Resigns', The Observer, 20 November 1921, 14.

81 T.P. Gill, 'Address to the Council of Agriculture', Department of Agriculture and Technical Instruction Journal, 20.1 (1919), 12-19.

82 HCPP [Cmd. 808] Department of Agriculture and Technical Instruction for Ireland, Report of the Departmental Committee on the Decline of Dairying in Ireland (1920), 4.

83 IAOS, Annual Report, 1919, 11.

84 T. O’Donovan, Abbeydorney, to R.A. Anderson, Dublin, 27 August 1919, NAI $1088 / 2 / 4$.

85 IAOS, Annual Report, 1908, 7.

86 Ingrid Henriksen, Morten Hviid and Paul R. Sharp, 'Law and Peace: Contracts and the Success of the Danish Dairy Cooperatives', Journal of Economic History, 72.1 (2012), 197-224.

87 Ingrid Henriksen, Eoin McLaughlin, and Paul Sharp, 'Contracts and Co-operation: the Relative Failure of the Irish Dairy Industry in the Late Nineteenth Century Reconsidered', European Review of Economic History, 19 (2015), 412-431.

88 John Byrne's Affidavit Concerning Events Surrounding the Burning of the Society, 9 April 1921, NAI 1088/70/1.

89 'McEllistrim v Ballymacelligott Co-operative Agricultural and Dairy Society Limited [1918-19] All E R Rep Ext 1294', in Lexis Library, www.lexisnexis.com/uk/legal/ 
results/enhdocview.do?docLinkInd=true\&ersKey=23_T18046105861\&format=GNB FULL\&startDocNo=0\&resultsUrlKey=0_T18046105862\&backKey=20_T1804610 $5863 \&$ csi $=279847 \&$ doc $\mathrm{No}=1 \&$ scrollToPosition $=0$ [accessed 29 August 2013]. Also see M.J. Trebilcock, The Common Law of Restraint of Trade: A Legal and Economic Analysis (London: Carswell, Sweet \& Maxwell, 1986), 324.

90 'Private Interests and the Co-operative Movement', Irish Homestead, 2 August 1919, 570-571; Patrick Bolger, The Irish Co-operative Movement: Its History and Development (Dublin: Institute of Public Administration, 1977), 205-206.

91 IAOS, Annual Report, 1908, 9-10.

92 Lionel Smith-Gordon and Laurence C Staples, Rural Reconstruction in Ireland: A Record of Co-operative Organisation (London: P.S. King and Co., 1917), 141-147.

93 L.P. Byrne, Twenty-One Years of the IAWS, 1897-1918 (Dublin: IAWS, 1919), 78-80.

94 IAOS, Annual Report, 1919, 12.

95 IAOS, Annual Report, 1920, 16.

96 IAOS, Annual Report, 1920, 16-17.

97 Rev. M O’Flanagan, Co-operation (Dublin: Cumann Léigheacht an Phobail, 1922), 2.

98 O'Flanagan, Co-operation, 9.

99 IAOS, Annual Report, 1920, 10-11.

100 IAOS, Annual Report, 1920, 11.

101 Bard of Rathmore, 'Farmer's Factory in Rathmore', Irish Homestead, 10 May 1919, 339-340.

102 R.A. Anderson, Dublin, to John O'Leary, Rathmore, 6 May 1919, NAI 1088/798/1; Jeremiah Murphy, When Youth was Mine: A Memoir of Kerry, 1902-1925 (Dublin: Mentor Press, 1998), 40.

103 C.C. Riddall, Limerick, to Anderson, Dublin, 3 May 1919, NAI 1088/798/1.

104 J.H. McKee, Rathmore, to R.A. Anderson, Dublin, 26 July 1919, NAI 1088/798/1.

105 C.C. Riddall, Limerick, to John O’Leary, Rathmore, 31 January 1920, NAI 1088/798/1.

106 James Fant's Report re Attendance at Rathmore Committee Meeting, 13 September 1920, NAI 1088/798/2.

107 Correspondence between Fant and de Lacy, Rathmore, 3 September 1920, 27 November 1920, 28 November 1920 and 18 December 1920, NAI 1088/798/2.

108 IAOS, Annual Report, 1920, 17.

109 Frantz Fanon, The Wretched of the Earth (London: Penguin, 2001), 27.

110 Ex-servicemen referred to as such on account of the colour of their uniforms.

111 Colm Campbell, Emergency Law in Ireland, 1918-1925 (Oxford: Clarendon Press, 1994), 21.

112 Julia Eichenberg, 'The Dark Side of Independence: Paramilitary Violence in Ireland and Poland After the First World War', Contemporary European History, 19.3 (2010), 231-248.

113 Gallagher, My Story, 154.

114 Peter Hart, The IRA at War, 1916-1923 (Oxford: Oxford University Press, 2003), 34-37. 
115 Daly, First Department, 78.

116 Peter Hart, The IRA and its Enemies: Violence and Community in Cork, 1916-1923 (Oxford: Oxford University Press, 1998), 81-82.

117 The Burning of Irish Creameries', Manchester Guardian, 30 October 1920, 11.

118 'Terrorism in Kerry', The Kerryman, 30 October 1920.

119 C.C. Riddall to R.A. Anderson, Dublin, 6 October 1919, NAI 1088/800/2.

120 William O'Connell, Rattoo to R.A. Anderson, 4 November 1920, NAI 1088/800/2.

121 W.P. Clifford, Limerick, to William O’Connell, Rattoo, 19 March 1921, NAI 1088/800/2.

122 Horace Plunkett, 'Irish Creameries', The Times, 7 September 1920, 6.

123 'To Pacify Ireland by Stern Methods, Says Lloyd George', New York Times, 10 October 1920.

124 Æ, 'Irish Creameries', The Times, 23 August 1920, 6.

125 Æ, A Plea for Justice: Being a Demand for a Public Enquiry into the Attacks upon the Co-operative Societies in Ireland (Dublin: Irish Homestead, 1920), 2.

126 Manchester Guardian, 30 October 1920, 12 November 1920 and 27 May 1921.

127 Labour Party, Report of the Labour Commission, 1.

128 'Labour Mission's Peace Effort', Manchester Guardian, 3 December 1920, 10.

129 Labour Party, Report of the Labour Commission, 7-8. This point is also made by Francis Costello, The Irish Revolution and its Aftermath, 1916-1923 (Dublin: Irish Academic Press, 2003), 83.

130 'Diabolical Attack Upon Co-operation', Co-operative News, 28 August 1920.

131 'Those Creameries', Co-operative News, 27 November 1920, 9.

132 James Daly, Rathmore, to R.A. Anderson, 12 May 1921, NAI 1088/798/3.

133 N.W. O’Brien, Report of Visit to Rathmore, 1 June 1921, NAI 1088/798/3.

134 Thomas de Lacy to James Fant, 2 July 1921 and 5 July 1921, NAI 1088/798/3.

135 Bureau of Military History, Thomas McEllistrim Witness Statement, 0882.

136 Bureau of Military History, Bessie Cahill Witness Statement, 1143.

137 Labour Party [Great Britain], Report of the Labour Commission to Ireland (London: Caledonian Press, 1921), 44-45.

138 Labour Party, Report of the Labour Commission, 51.

139 R.A. Anderson to Fant, 1 July 1921, NAI 1088/70/1.

140 John Byrne's Affidavit, 9 April 1921, NAI 1088/70/1.

141 'Ireland's Economic Decay', Manchester Guardian, 8 February 1921, 6.

142 John O’Connell, Tralee to Manager, Ardfert Co-operative Society, Ardfert, 19 April 1922, KLHA, O’Connell Papers.

143 'Creameries Closed by Military as a Punishment to Farmers', Manchester Guardian, 27 May 1921, 7.

144 T. O’Donovan, Abbeydorney, to Irish Co-operative Agency Society, Limerick, 24 March 1921, NAI 1088/2/4.

145 T. O’Donovan to R.A. Anderson, 15 June 1921, NAI 1088/2/4.

146 Nicholas O'Brien to R.A. Anderson, 22 June 1921, NAI 1088/2/4.

147 Nicholas O’Brien to R.A. Anderson, 22 June 1921 [handwritten addition by James Fant, 30 June 1921], NAI 1088/2/4. 
148 Alvin Jackson, Ireland, 1798-1998: Politics and War (Oxford: Blackwell Publishers Ltd., 1999), 257; Lee, Ireland, 1912-1985, 47. For an account of the Anglo-Irish Treaty negotiations, see The Earl of Longford, Frank Pakenham, Peace by Ordeal: An Account, From First-Hand Sources, of the Negotiation and Signature of the Anglo-Irish Treaty 1921 (London: Jonathan Cape, 1935).

149 John Jones, Ballymacelligott, to R.A. Anderson, Dublin, 3 July 1921, NAI 1088/70/1.

150 James G. Douglas, Memoirs of Senator James G. Douglas: Concerned Citizen, ed. by J. Anthony Gaughan (Dublin: University College Dublin Press, 1998), 138-140.

151 'American Relief for Irish Distress', Manchester Guardian, 11 February 1921, 9.

152 'Rebuilding Destroyed Irish Industries', Manchester Guardian, 13 May 1921, 9.

153 Bolger, The Irish Co-operative Movement, 212.

154 R.A. Anderson to James Fant, 1 July 1921, NAI 1088/70/1.

155 Thomas de Lacy to C.C. Riddall, 19 July 1921, NAI 1088/798/3.

156 James Fant's Report, 2 August 1921, NAI 1088/798/3.

157 N.W. O’Brien's Report, 18 October 1921, NAI 1088/798/3.

158 N.W. O’Brien's Report, 28 October 1921, NAI 1088/798/3.

159 Secretary of Dairy Disposal Company to Secretary of the IAOS, 9 March 1936, NAI 1088/798/7.

160 IAOS, Annual Report, 1921, 5.

161 IAOS, Annual Report, 1921, 5. 